\title{
A Novel Artificial Intelligence based Hybrid Maximum Power Point Tracking Technique for Solar Photovoltaic System
}

Mohammad junaid Khan ( $\square$ mohammad.khan444@gmail.com )

\section{Original article}

Keywords: Photo-Voltaic, Maximum Power Point Tracking Algorithm, Perturb and Observe, fuzzy logic controller, Artificial Neural Network, proposed hybrid Controller

Posted Date: September 28th, 2020

DOI: https://doi.org/10.21203/rs.3.rs-78775/v1

License: (c) (i) This work is licensed under a Creative Commons Attribution 4.0 International License. Read Full License 


\title{
A Novel Artificial Intelligence based Hybrid Maximum Power Point Tracking Technique for Solar Photovoltaic System
}

\author{
Mohammad Junaid Khan ${ }^{1 *}$ \\ ${ }^{1}$ Department of Electrical and Electronics Engineering, Mewat Engineering College \\ Nuh, Haryana, India \\ *Corresponding Author Email: mohammad.khan444@gmail.com
}

\begin{abstract}
Backgrounds: Solar photo-voltaic (PV) arrays have non-linear characteristics with distinctive maximum power point (MPP) which relies on ecological conditions such as solar radiation and ambient temperature. In order to obtain continuous maximum power (MP) from PV arrays under varying ecological conditions, maximum power point tracking (MPPT) control methods are employed. MPPT is utilized to extract MP from the solar PV array, high-performance soft computing techniques can be used as an MPPT technique.
\end{abstract}

Results: In order to show the feasibility and performance of the proposed Artificial Intelligence based Perturbe and Observe (AIAPO) MPPT controller, a simulation analysis has been carried out using the PV system. Combined results with different MPPT systems for power, voltage and current waveforms are the output values increase to $272.4 \mathrm{~W}, 157 \mathrm{~V}$ and $1.74 \mathrm{~A}$ respectively. Using proposed AIAPO MPPT provides more accurate and stable result as compared to Perturbe and Observe (PO), Fuzzy Logic (FL) and Artificial Neural Network (ANN) based MPPT Technique. As per the experimentation performed by various MPPT techniques are carried out for PV system which are clearly indicating that the comparative analysis of power, voltage and current performance of PV system (i.e. have been recorded $272.4 \mathrm{~W}$, $157 \mathrm{~V}$ and 1.74A) using proposed MPPT method which is better than the PO based MPPT (i.e. $169.1 \mathrm{~W}, 127 \mathrm{~V}, 1.43 \mathrm{~A}$ ), FL based MPPT technique (i.e. $256.9 \mathrm{~W}, 152 \mathrm{~V}$, 1.69A) and ANN based MPPT technique (i.e. $265 \mathrm{~W}, 154 \mathrm{~V}, 1.71 \mathrm{~A}$ ) correspondingly.

Conclusions: The aim of this paper is to track MPP from the solar PV array by the proposed hybrid controller for irradiation changes and comparing results with PO, FL and ANN based MPPT controllers. Different MPPT techniques have been used to compute MPP and improved efficiency of the PV panel. AIAPO, ANN, FL and PO MPPT methods have been chosen to obtain this objective. Simulation results showing that the system in which proposed control method has been used gives better performance and reduce fluctuations of the MPP as compared to PO, FL and ANN based MPPT technique at rapid changes of irradiation. In order to fabricate a reliable and real time hybrid system, there is a massive scope of research to develop multiinput renewable energy systems.

Keywords: Photo-Voltaic; Maximum Power Point Tracking Algorithm; Perturb and Observe; fuzzy logic controller; Artificial Neural Network; proposed hybrid Controller. 


\section{Introduction}

The demand for power is increasing day-by-day throughout the world. The conventional power sources are reducing gradually and produce emissions of greenhouse gases to the environment. This issue can be overcome, to encourage society towards the innovative development of alternative renewable energy (RE) sources. RE sources are used in gridconnected and can be found in rural and remote areas where the public grid is not available. PV array is the device that converts solar energy into electrical energy (Spagnuolo, Petrone, Araujo \& Cecati, 2010; Dimitrijevic, Stosovic, \& Litovski, 2020). Some benefits are offered by RE sources such as PV system. PV systems are sustainable, clean and easy to maintain. It is nonlinear RE system; numerous MPPT control techniques have been proposed and established in order to sustain PV energy system operation at MPP. MPPT techniques are used to track the MPP by minimum deviations. PO, Incremental Conductance (INC) and hill climbing methods are generally used in yielding the MPP at a uniform level of insolation (Femia, Petrone, Spagnuolo \& Vitelli, 2009; Basoglu, 2018). The comparative analysis of PO and INC algorithm has been done in MATLAB ${ }^{\mathrm{TM}}$ /SIMULINK $^{\mathrm{TM}}$ environment (Ahmed, Abdullah, Abdelaal 2016). These control techniques fail under nonuniform insolation level. Other MPPT control techniques (Khan \& Mathew, 2016a) such as FL Controller, Neural Network (NN) control method and Adaptive Neuro-Fuzzy Inference System (ANFIS) etc. are Artificial Intelligence (AI) based MPPT control methods. They have the advantage that no requirement of information of internal factors of the solar PV system including less computational efforts and compact outcome in favour of the multivariable problems. (Sawant, Bhattar \& Bhattar, 2017) have been described various MPPT techniques based on swarm intelligence and evolutionary techniques. The main goal is to familiarize guided artificial bee colony technique under rapidly changing conditions. The proposed Artificial Bee Colony (ABC) technique has a better result as compared to conventional MPPT techniques using MATLAB $^{\mathrm{TM}}$ / SIMULINK ${ }^{\mathrm{TM}}$ (Sawant, Lbhattar \& Bhattar, 2016). (Ulapane \& Abeyratne, 2014) has been presented the learned function for MP that has been validated through comparing the outputs of function i.e. Gaussian Process (GP) results in a contradiction of the manufacturer identified power values. (Mahalakshmi, Archana \& Komathi 2016) has been a proposed algorithm which is simulated in MATLAB ${ }^{\mathrm{TM}}$ / SIMULINK $^{\mathrm{TM}}$ environment, the simulation of active and reactive power which is control and analyzed using a Proportional Integral Derivative (PID) controller for maintain the stability of the system. PO based MPPT is used with micro-controller to control the duty-cycle of a dc-dc power converter for achieving the MP from PV module (Vivek, Ayshwarya, Amali \& Sree, 2016). Implementation of hardware using ARM Cortex-M3 32 bit microcontroller has been developed for $10 \mathrm{~W}$ PV array (Ravindran \& Sutaria, 2016). The proposed MPPT technique had provided fast and accurate tracking for every atmospheric condition and results validated by simulation in MATLAB ${ }^{\mathrm{TM}}$ / SIMULINK $^{\mathrm{TM}}$ (Shahana \& Linus, 2016). The FL controller based MPPT is provided better performance as compared to PO and Proportional Integral (PI) based MPPT techniques and is also validated with the experimental setup under variation of irradiation and temperature 
(Balasubramanian \& Singaravelu, 2012). (Nabizadeh, Alizadeh, Afifi \& Soltani, 2013) presented an FL controller based MPPT which obtained improved performance as compared to PI-based MPPT controller. FL based technique was compared with conventional PO MPPT technique for PV system which is simulated in MATLAB/SIMULINK environment (Bounechba, Bouzid, Nabti \& Benalla, 2014; Robles, Taborda \& Rodríguez, 2017; Khan \& Mathew, 2018c). Modelling of PV system using FL based MPPT technique has been designed by (Mahamudul, Saad, \& Ibrahim, 2013), proposed system was applied for three different PV Arrays such as SOLKAR for $36 \mathrm{~W}$, BP MXP for $60 \mathrm{~W}$ and $\mathrm{KC} 85 \mathrm{~T}$ for $87 \mathrm{~W}$. Simulation analysis of optimization and rule firing in FL based MPPT technique for PV system (Letting, Munda \& Hamam, 2014).

In this paper, different MPPT techniques such as PO, FL, ANN and proposed hybrid for PV system are implemented using MATLAB $^{\mathrm{TM}}$ / SIMULINK $^{\mathrm{TM}}$. Based on simulation results, the comparison of PO, FL, ANN and proposed hybrid MPPT methods has been carried out for finding MP track from the PV array due to variable irradiations and fixed temperature.

This paper is structured as follows: the mathematical model of the PV system is given in Section 2. Section 3 described the proposed model of PV system. The methodology is given in Section 4. The results and discussions are given in Section 5. Section 6 described the comparative analysis of different MPPT methods in PV system. Finally, conclusions are given in Section 7.

\section{Mathematical model of Photo-Voltaic System}

PV cell is defined as an electrical gadget which converts the light energy into electrical power by using semiconducting materials that display the PV impact. It is a type of PV cell characterized as an electrical device whose electrical variables like current, voltage and resistance, fluctuate in order to light. The solar cell equivalent circuit as illustrated in Fig. 1 (Lorenzo, 1994).

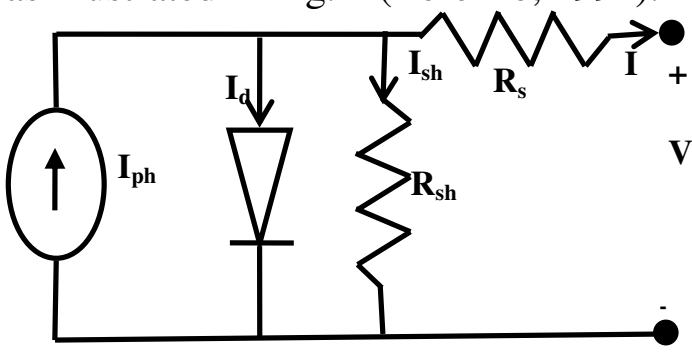

Fig. 1 Solar Cell Equivalent Circuit

The band gap of the semiconductor is a base energy which is required to energize an electron that is stuck in its bound state goes into a free state where it can partake in conduction. This model consists of a diode, resistance and a light created source which is arranged in parallel connection. The numerical articulations of the solar cell equivalent circuit of PV module are expressed as Eq. (1), (2) and (3) (Chu \& Chen, 2009).

$$
\begin{gathered}
I=I_{p h}-I_{d}\left[\exp \left(\frac{q V}{K_{v} A T}\right)-1\right](1) \\
I_{p h}=I_{r}\left[I_{s c r}+K_{i}\left(T-T_{r}\right)\right] \\
I_{d}=I_{o}\left[\frac{T}{T_{r}}\right] \exp \left(\frac{E_{g} q}{k A Q}\left[\frac{1}{T_{r}}-\frac{1}{T}\right]\right)
\end{gathered}
$$

where, $I=$ total current (A), $V=$ output voltage $(\mathrm{V}), T=$ temperature of solar cell, $q=$ electron charge, $K_{i}=$ temperature coefficient of short-circuit current, $I_{r}=$ irradiance of solar cell, $K_{v}=$ temperature coefficient of open circuit voltage and $k=$ Boltzmann's constant, $A$ $=$ ideality factor, $I_{p h}=\mathrm{PV}$ solar cell current, $I_{s c r}=$ short-circuit current at reference condition, $I_{d}=$ diode current, $I_{o}=$ saturation current at $T_{r,}, T_{r}=$ 
reference temperature, $Q=$ total electron charge, $E_{g}=$ band-gap energy.

\section{Proposed Photo-Voltaic System}

Proposed PV system contains the following mechanisms such as PV panel, a power boost converter, MPPT controller and resistive load. The duty cycle of the boost converter is measured using conventional and proposed MPPT algorithms. Fig. 2 shows the proposed block diagram of the PV renewable energy system. The main aim of the control system is to maximize the power generation with a variable irradiations from PV panel. Using MPPT method, it should ensure that the DC power is transformed to the load with high efficiency.

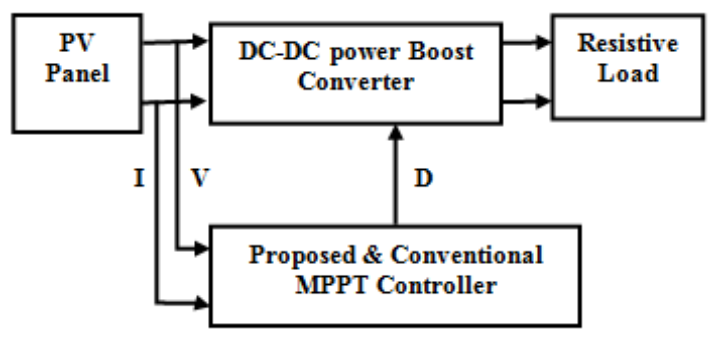

Fig. 2 Block Diagram of

Proposed PV Renewable Energy System

\section{Methodology}

MPPT technique is used for improving power from the solar-PV framework and transferring, energy into the load. A dc-dc power converter effectively transfers MP from the PV modules to the heap. By varying the duty-cycle, the load impedance for example observed by the source is altered and matched at the point of the peak power with the source therefore as to transfer the MP. MPPT controllers are required to maintain the operating point of $\mathrm{PV}$ arrays at its MPP. In this research article, Proposed hybrid MPPT technique has the leads of simple design and do not need the knowledge of the exact model. Instead, conventional MPPT controllers require full information about the performance of PV system.

\subsection{Perturbed and Observe Based MPPT}

PO control method is frequently used for achieving MP from PV system. This control technique uses humble feedback arrangement and modest dignified parameters.

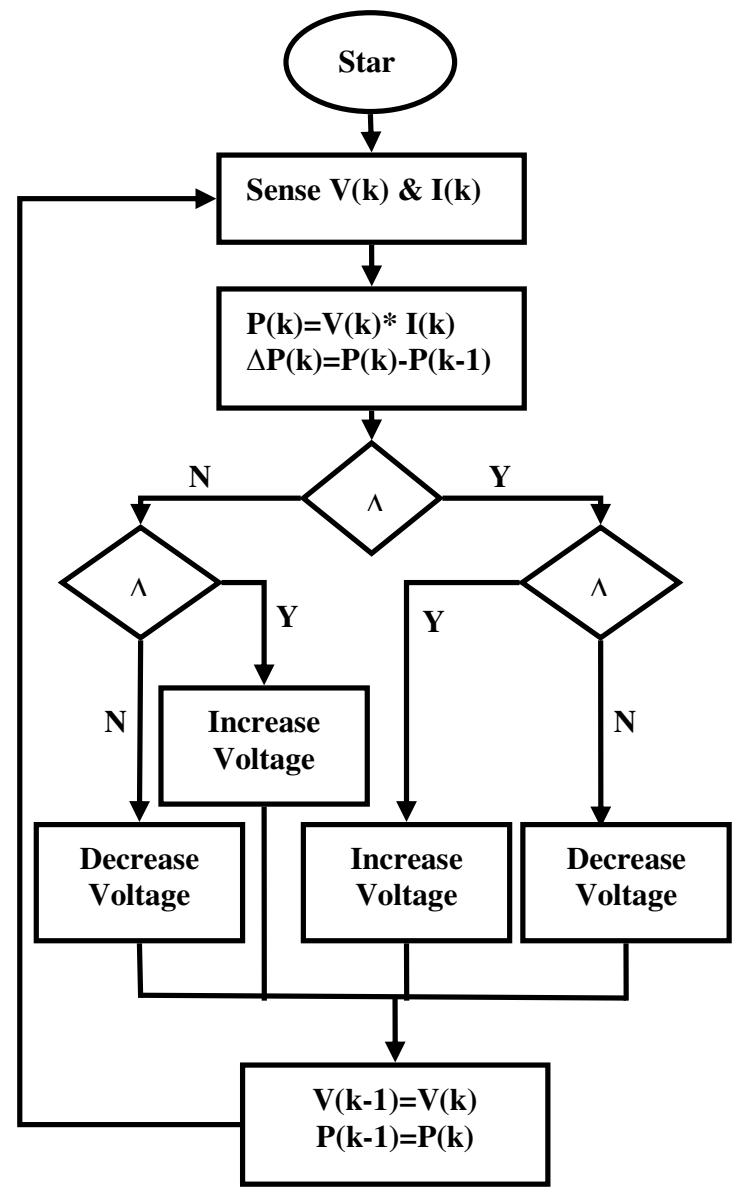

Fig. 3 Flow Chart of PO Control Method

In PO based MPPT technique, the voltage of solar-PV array has periodically specified a perturbation and analogous output power is matched by 
that at prior perturbing cycle (Hohm, Ropp, 2000). If the power rises due to the perturbation after that the perturbation is sustained in the identical track. Subsequently, the peak power is touched, the power at the MPP is zero and subsequent instantaneous decreases and then perturbation reverses as shown in Fig. 3.

\subsection{Fuzzy Logic Controller Based MPPT}

This method offers the benefit of being relatively easy to design and robust due to no requirement of knowledge of the PV panel parameters. FL Controller offers fast results by expertise and measured database. In the algorithm of FL based MPPT is based on three steps such as fuzzification, inferences and defuzzification (Letting, Munda \& Hamam, 2014; Liu, Yang, Yang \& Hsu, 2015). The fuzzification, FL inference system and defuzzification are the three major stages of FL. The fuzzification is the alteration of real data into a fuzzy linguistic variable based on the membership function. A defuzzification is the change of the output linguistic variable into a suitable control signal. The IF-THEN relations between the input and output variable signal are set in the fuzzy inference system block. The scheme such an FL based MPPT technique has been shown in Fig. 4 and Fig. 5 illustrations the block diagram of FL approach. According to the FL based MPPT technique in Fig. 5, the two inputs are fed to the fuzzification that is error $(E(k))$ and change in error $(\Delta E(k))$, based on the rule base, it yields optimum duty-cycle using defuzzification of the FL controller. Duty cycle $(D)$ associated with fuzzy sets which are described as Zero Error (ZE), Negative Big (NB), Positive Big (PB), Negative Medium (NM), Positive Medium (PM), Negative Small (NS) and Positive Small (PS), are defined to designate each linguistic variable. The fuzzy rules of the proposed system are given in Table 1.

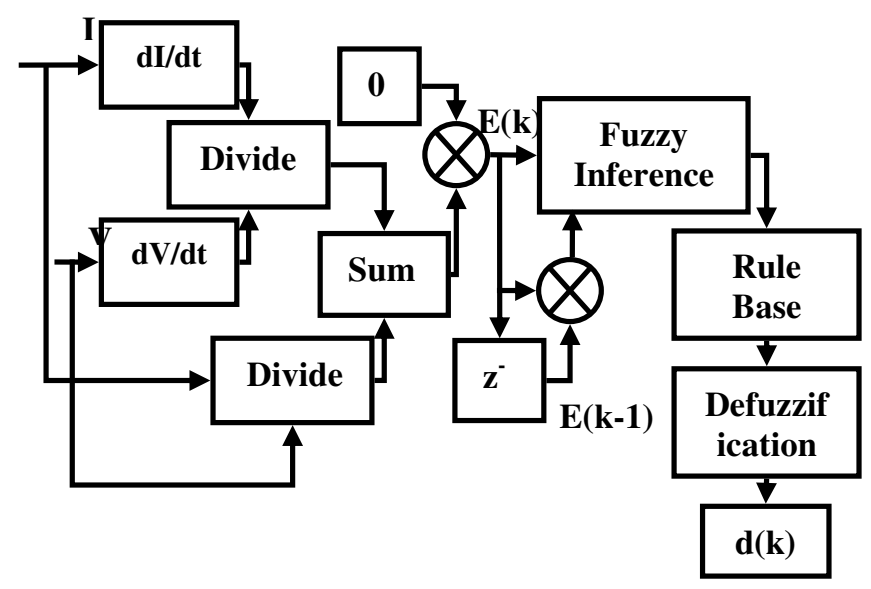

Fig. 4 Block Diagram of FL Based MPPT Technique

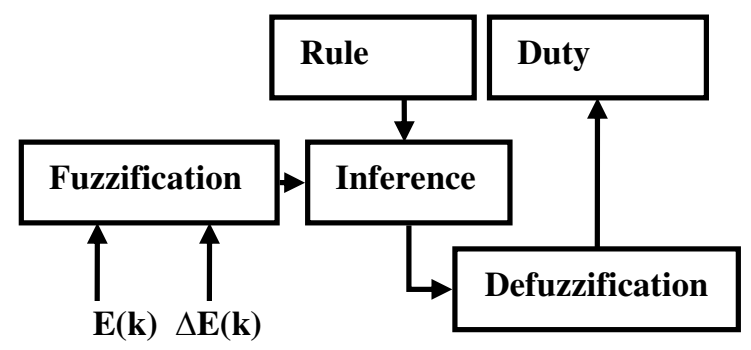

Fig. 5 Block Diagram of FL Approach

Table 1 Rules of the FL controller

\begin{tabular}{|c|c|c|c|c|c|c|c|}
\hline$\frac{E(\mathbf{k}) \vec{P}}{\Delta E(k)}$ & NB & $\begin{array}{l}\mathbf{N} \\
\mathbf{M}\end{array}$ & $\begin{array}{l}\mathbf{N} \\
\mathbf{S}\end{array}$ & $\mathbf{Z E}$ & PS & $\begin{array}{l}\mathbf{P} \\
\mathbf{M}\end{array}$ & PB \\
\hline NB & ZE & $\mathrm{ZE}$ & $\begin{array}{l}\mathrm{N} \\
\mathrm{S}\end{array}$ & $\begin{array}{l}\mathrm{N} \\
\mathrm{M}\end{array}$ & $\begin{array}{l}\mathrm{P} \\
\mathrm{M}\end{array}$ & $\begin{array}{l}\mathrm{P} \\
\mathrm{M}\end{array}$ & $\mathrm{PB}$ \\
\hline NM & $\mathrm{ZE}$ & ZE & $\begin{array}{l}Z \\
E\end{array}$ & NS & PS & $\begin{array}{l}\mathrm{P} \\
\mathrm{M}\end{array}$ & PB \\
\hline NS & ZE & ZE & $\begin{array}{l}Z \\
E\end{array}$ & ZE & PS & $\begin{array}{l}\mathrm{P} \\
\mathrm{M}\end{array}$ & PB \\
\hline $\mathbf{Z E}$ & $\mathrm{NB}$ & $\begin{array}{l}\mathrm{N} \\
\mathrm{M}\end{array}$ & $\begin{array}{l}\mathrm{N} \\
\mathrm{M}\end{array}$ & $\mathrm{ZE}$ & PS & $\begin{array}{l}\mathrm{P} \\
\mathrm{M}\end{array}$ & $\mathrm{PB}$ \\
\hline $\begin{array}{l}\text { PS } \\
\end{array}$ & BB & $\begin{array}{l}\mathrm{N} \\
\mathrm{M}\end{array}$ & $\begin{array}{l}\mathrm{N} \\
\mathrm{M}\end{array}$ & $\mathrm{ZE}$ & $\mathrm{ZE}$ & $\overline{\mathrm{ZE}}$ & $\mathrm{ZE}$ \\
\hline PM & NB & $\begin{array}{l}\mathrm{N} \\
\mathrm{M}\end{array}$ & $\begin{array}{l}\mathrm{N} \\
\mathrm{M}\end{array}$ & PS & ZE & ZE & $\mathrm{ZE}$ \\
\hline PB & $\mathrm{NB}$ & $\begin{array}{l}\mathrm{N} \\
\mathrm{M}\end{array}$ & $\begin{array}{l}\mathrm{N} \\
\mathrm{M}\end{array}$ & $\mathrm{PM}$ & PS & $\mathrm{ZE}$ & $\mathrm{ZE}$ \\
\hline
\end{tabular}

The membership functions of input and output variables are shown in Fig. 6 to Fig. 8 and Fig. 9 shows the 
surface viewer of FL controller. In FL controller design, one should detect the variables of the controller and find the sets that define the values of each linguistic variable and their range. The input variables of the FL Controller are the $E(k)$ and $\Delta E(k)$ of the fuzzification. The output of the FL Controller is the change in duty-cycle $(\Delta D)$ of the pulse width modulation (PWM) signal, which controls the output voltage. The linguistic variable ranges are -10 to 10 and -5 to 5 for input variables and -0.2 to 0.2 for output variable. The FL based MPPT does not necessitate the exact information of the PV model for its design. They are given by Eq. (4) to (7) (Algazar, Al-Monier, El-Halim \& Salem, 2012):

$$
\begin{aligned}
& E(k)=\frac{\Delta I}{\Delta V}+\frac{I}{V} \\
& \Delta E(k)=E(k)-E(k-1) \\
& \Delta I=I(k)-I(k-1) \\
& \Delta V=V(k)-V(k-1)
\end{aligned}
$$

where, $I$ is the output current and $V$ is the output voltage of PV module. In the proposed approach, the fuzzy inference (FI) can be carried out with one of the different obtainable methods. FL controller (Mamdani's method) based MPPT has been used, and defuzzification centre in favour of gravity technique is used to compute the yield of FL controller (change in dutyration: $\Delta D$ ).

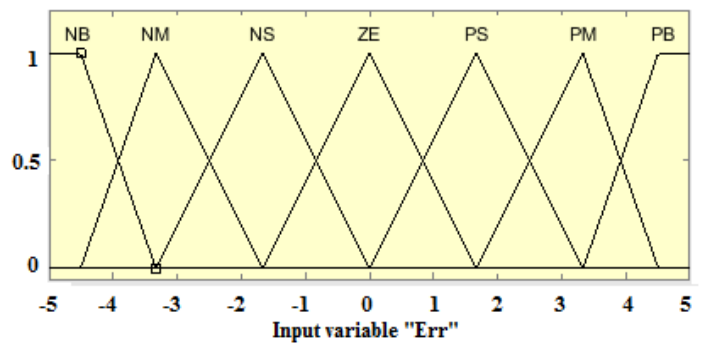

Fig. 6 Membership Function (MF) of Input (Err)

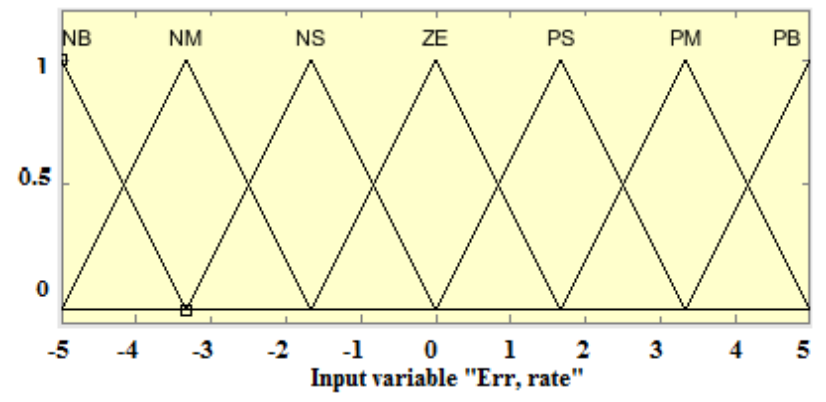

Fig. 7 Membership Function (MF) of Input (Err,ate)

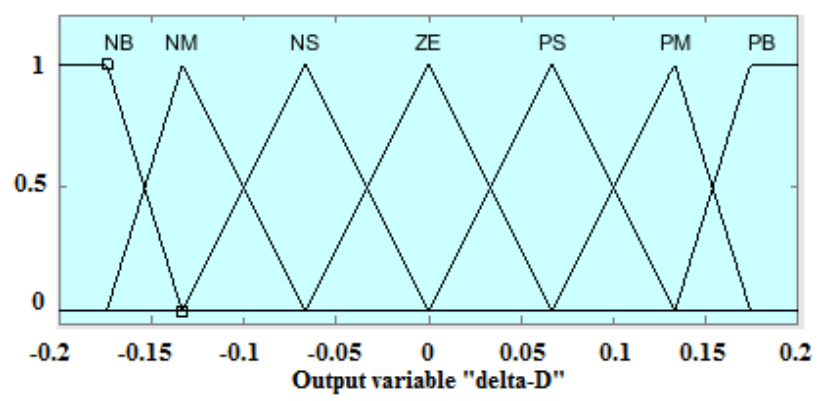

Fig. 8 Membership Function (MF) of Output (delta-D)

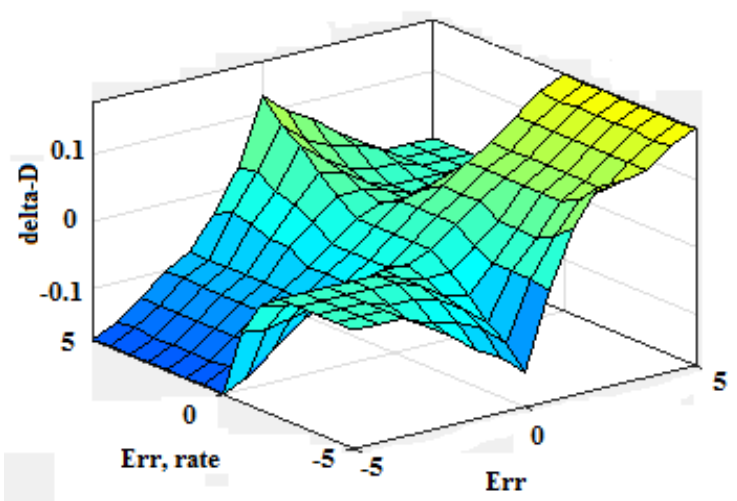

Fig. 9 Surface Viewer of FL Controller

\subsection{Artificial Neural Network based MPPT}

ANN architecture offers the best solution for the dynamic and non-linear systems. The back-propagation network is more common among different types of neural networks and is useful. The MPPT technique based on ANN 
operates like a black box model, and detailed knowledge about the solar PV system is not required (Selami, Ahmet \& Berat, 2020; El-Helw, Magdy \& Marei, 2017; Khan \& Mathew 2019b).

Two layer feed forward ANN architecture has been used in the present research work to generate duty-ratio to control MPP. The external data (i.e. voltage and current) is provided by the input region. The hidden layer includes the hidden neurons that receive input area data and transfer it to output layer. Fig. 10 shows the ANN model.

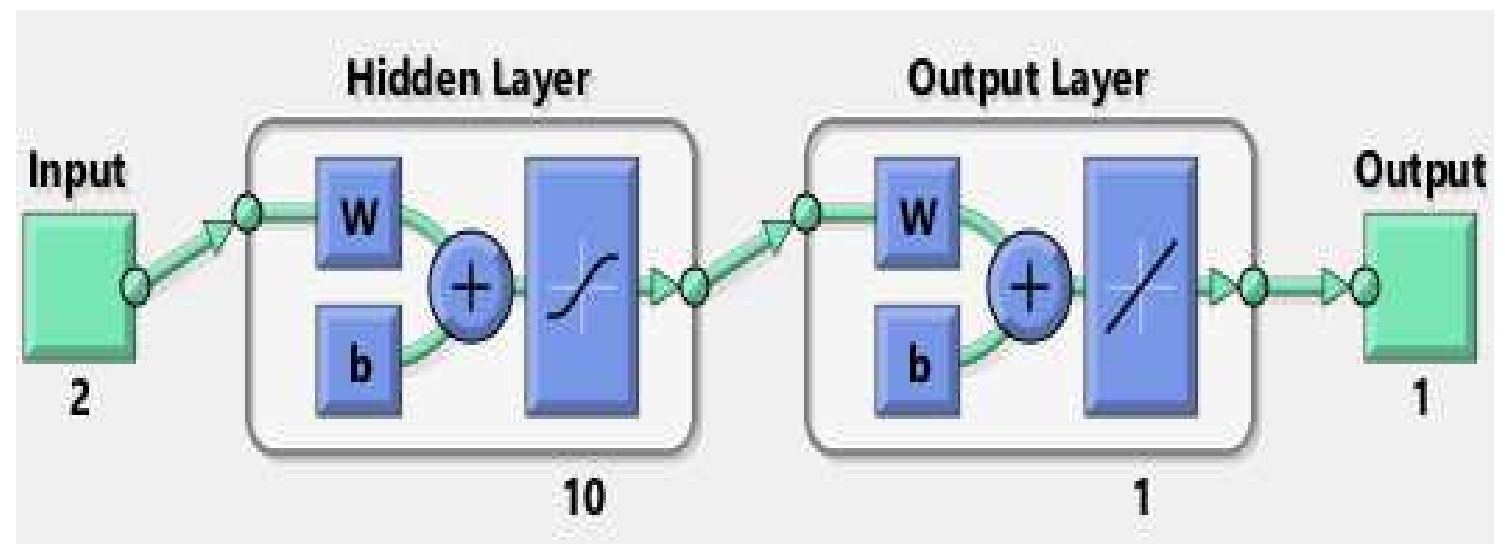

Fig. 10 ANN Model

Function fitting is the process of training a neural network on a set of inputs to generate a set of target outputs associated with that. When the neural network suits the data, it forms a generalization of the relationship between input and output, and can be used to produce outputs for inputs on which it was not even educated. During training, training data is provided to the network, and the network is modified as per its error. Validation data was used to test the generalization of the network, and to stop training when generalization stops improving. The test data provide an independent network output assessment before and after preparation.

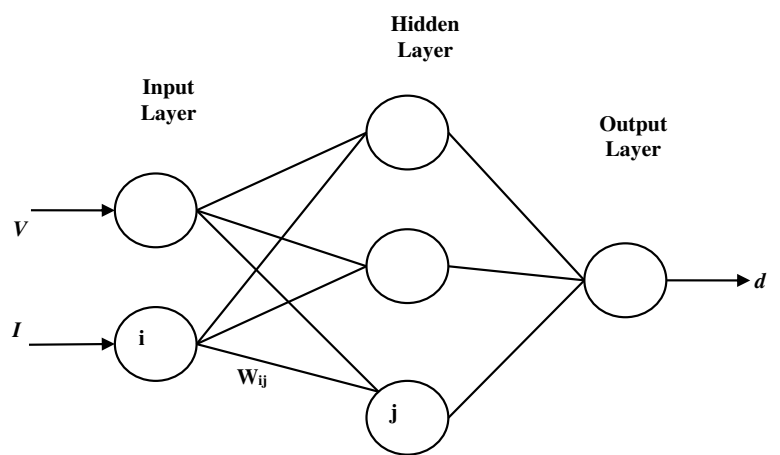

Fig. 11 ANN based MPPT Technique Block diagram of ANN based MPPT method is shown in Fig. 11. The inputs can be voltage, current and/or environmental data like solar radiation. The output of the neural network is the duty-ratio used to operate the dc-dc boost converter at MPP.

\subsection{Proposed Algorithm of Artificial Intelligence Based Adaptive Perturb and Observe (AIAPO) MPPT Controller}

The proposed MPPT algorithm determines the MPP and enhances the efficiency of the RE system. As shown in flowchart of Fig. 12, which operates 
by varying the duty cycle of the dc-dc converter depends on the requirement of converters. Consequently varying the output voltage of the PV system, and observe the resulting power to increase or decrease the duty cycle in the next cycle. If the increase of duty cycle produces an increase of the power, then the direction of the perturbation signal is the same as the previous cycle. Conflicting, if the perturbation duty cycle produces a decrease of the power, then the direction of perturbation signal is the opposite from the previous cycle. The increase or decrease in duty cycle is based on the perturbation $(\Delta D)$ which is generated by AI system.

AI algorithm receives the voltage and current data from PV module. Using Eq. (4) to (7), to calculating the $E(k)$ and $\Delta E(k)$. These are the inputs of FL controller. FL controller produces the optimum perturbation (i.e. $\Delta D$ ) by using fuzzy process such as fuzzyfication, inference and defuzzification. $\Delta D$ is change automatically with respect to change of irradiation in solar panel which is feed into the PO method as shown in Fig. 19. PO algorithm receives voltage and current data for computing duty-ratio. The initial values of the PO MPPT parameters can be set (i.e. initial value (0.8), upper limit (0.95), and lower limit (0.1)), including nominal duty-ratio, maximum and minimum values of the duty-ratio and $\Delta D$ is automatically change by FL based MPPT controller. The FL based MPPT technique produces an optimal change of dutycycle or perturbation $(\Delta D)$, which is fed into the PO based MPPT technique and thus produces an optimum value of duty ratio $(D)$. This $D$ value is then fed into the corresponding DC-DC converter.

The flowchart of AIAPO MPPT Controller (shown in Fig. 12) has been implemented by using MATLAB ${ }^{\mathrm{TM}}$
/SIMULINK $^{\mathrm{TM}}$ and MATLAB function of PO MPPT controller is shown in Fig. 19. A novel hybrid technique which is a combination of FL based MPPT technique and adaptive PO based MPPT technique has been employed. Since, the FL controller as described in section 4.2 , with the membership functions and rule base for PV system has been employed here for the development of the subsystem as shown in Fig. 19.

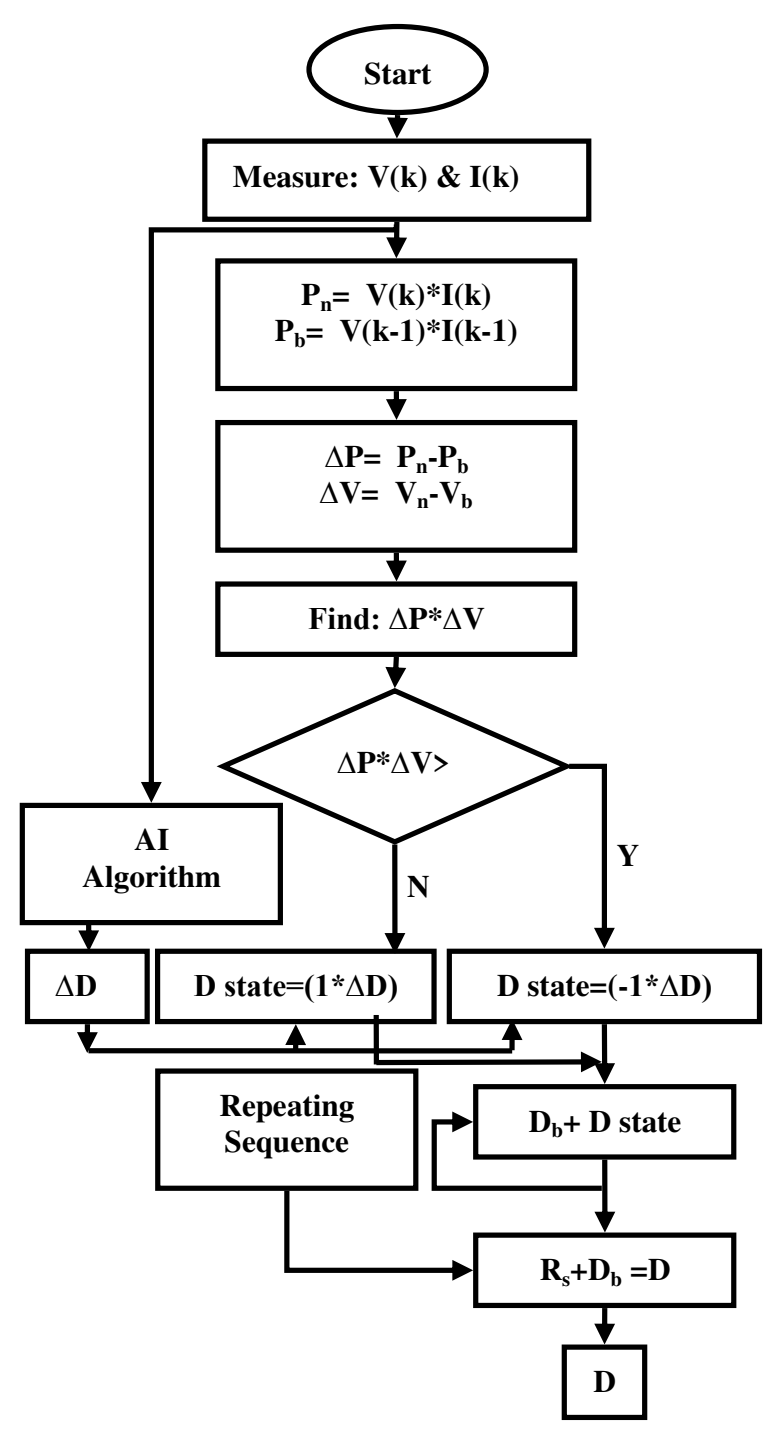

Fig. 12 Flowchart of AIAPO MPPT Controller

The developments of AI controller are increasing due to its ability to solve the complex 
mathematical model in an easier way. The FL is a most widely used AI, which works on human behaviour and there is no need to know the actual mathematical model for generating the results. The FL controller is more flexible than a conventional controller, the oscillation at MPP and tracking time are the major issue of conventional PO MPPT. The proposed hybrid MPPT method is used to overcome the drawback of conventional MPPT and FL controller, but it increases the mathematical computation of controller design.

In this paper, the duty-cycle adjusted by the proposed hybrid MPPT controller to achieve the MP tracking for improving the efficiency of the proposed system. The features are estimated to improve power track with reducing the fluctuations of output power and enhance the transient performance.

where, $\Delta P=P(k)-P(k-1), \Delta V=$ $V(k)-V(k-1), D$ state is the increment or decrement step according to perturbation $(\Delta D)$.

\subsection{Simulation Model of PV System using MATLAB ${ }^{\text {TM }} /$ SIMULINK ${ }^{\text {TM }}$}

A simulation model of the proposed solar-PV system consists of PV arrays, boost converter, PO, FL, ANN and proposed AIAPO MPPT techniques, and resistive load. The parameters of the proposed system are given in Table 2 .

Table 2 Parameters and Values of proposed PV System

\begin{tabular}{|c|c|}
\hline Parameters & Values \\
\hline $\begin{array}{l}\text { Open Circuit Voltage } \\
\left(\mathrm{V}_{\mathrm{oc}}\right)\end{array}$ & $44.00 \mathrm{~V}$ \\
\hline $\begin{array}{l}\text { The voltage at MPP } \\
\left(\mathrm{V}_{\mathrm{mp}}\right)\end{array}$ & $34.70 \mathrm{~V}$ \\
\hline Current at $\operatorname{MPP}\left(\mathrm{V}_{\mathrm{mp}}\right)$ & $7.80 \mathrm{~V}$ \\
\hline $\begin{array}{l}\text { Short Circuit Current } \\
\left(\mathrm{I}_{\mathrm{sc}}\right)\end{array}$ & $8.10 \mathrm{~A}$ \\
\hline Maximum Power (W) & $270.66 \mathrm{~W}$ \\
\hline Cells per Module & 72 \\
\hline $\begin{array}{l}\text { Series Connected } \\
\text { Module per String }\end{array}$ & 2 \\
\hline $\begin{array}{l}\text { Open Circuit Voltage } \\
\text { Temperature Coefficient } \\
\left(\mathrm{k}_{\mathrm{v}}\right)\end{array}$ & $-0.36\left(\% /{ }^{\circ} \mathrm{C}\right)$ \\
\hline Short-circuit current & 0.025 \\
\hline $\begin{array}{l}\text { Temperature Coefficient } \\
\left(\mathrm{k}_{\mathrm{i}}\right)\end{array}$ & $\left(\% /{ }^{\circ} \mathrm{C}\right)$ \\
\hline Switches Used & IGBT \\
\hline Diodes Used & P-N Diode \\
\hline $\begin{array}{l}\text { Saturation Current of } \\
\text { Diode }\end{array}$ & $2.5 * 10^{-10} \mathrm{~A}$ \\
\hline Ideality Factor of Diode & 0.982 \\
\hline Input Resistance $\left(\mathrm{R}_{\mathrm{in}}\right)$ & $1.10 \Omega$ \\
\hline Input Capacitance $\left(\mathrm{C}_{\mathrm{in}}\right)$ & $2000.00 \mu \mathrm{F}$ \\
\hline Inductance (L) & $10.00 \mathrm{mH}$ \\
\hline $\begin{array}{l}\text { Output Capacitance } \\
\left(\mathrm{C}_{\text {out }}\right)\end{array}$ & $2000.00 \mu \mathrm{F}$ \\
\hline Load Resistance $\left(\mathrm{R}_{\mathrm{L}}\right)$ & $90.00 \Omega$ \\
\hline
\end{tabular}

The simulation model of the solar-PV system with boost converter using MPPT Methods is shown in Fig. 13. The various MPPT techniques such as PO, FL, ANN and proposed AIAPO under following conditions are simulated. Fig. 14 shows the irradiation pattern of input for the PV array, in this pattern the rapid changing of radiations from 0.5 to 1 seconds at $25^{\circ} \mathrm{C}$ constant temperature have been taken. 


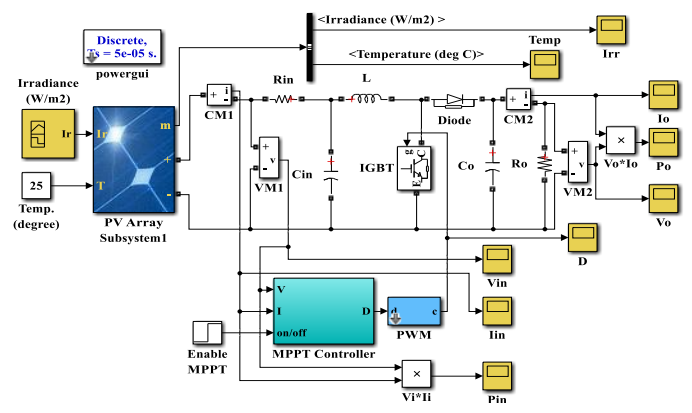

Fig. 13 Simulation Model of Solar-PV System using MPPT Controller

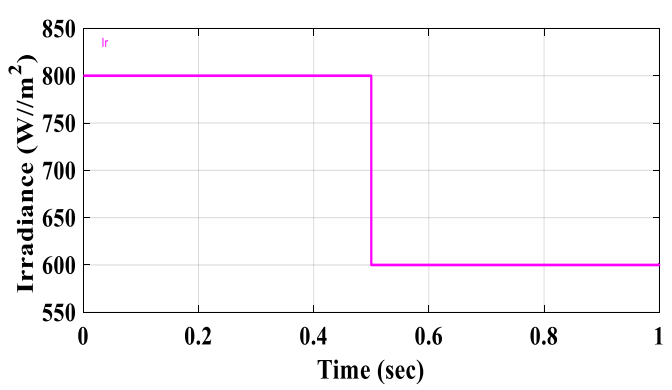

Fig. 14 Irradiation Pattern of Input for PV Panel

Fig. 15 and Fig. 16 show the subsystems of PO and FL MPPT methods. The investigator analyzed the system by including the subsystem of PO and FL controllers in the block MPPT controller in the simulation model shown in Fig. 13.

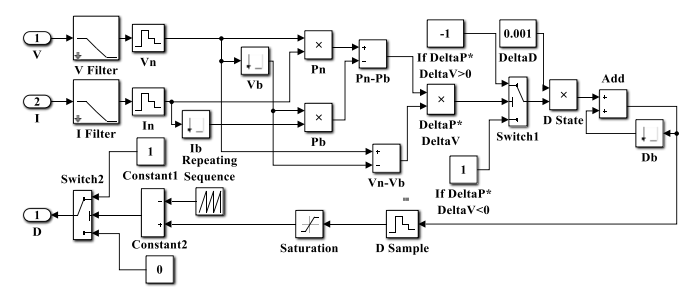

Fig. 15 Subsystem of PO Controller

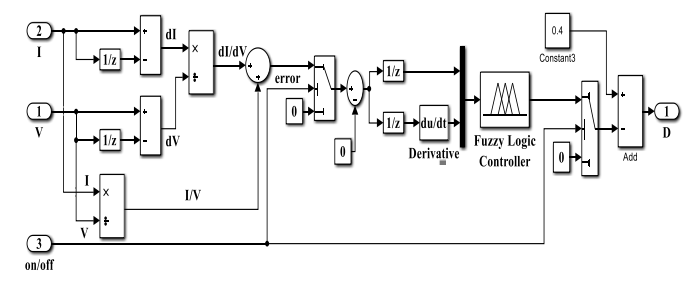

Fig. 16 Subsystem of Fuzzy Logic Controller
The input data for the network training can be derived from the results of experimental measurements or model-based simulation. After training with the input data the ANN can monitor the MPP. Two layer neural feed-forward networks with ten sigmoid hidden neurons is modeled using MATLABTM / SIMULINKTM ANN toolbox. The network was trained using the Levenberg-Marquardt back propagation algorithm, using a simulation collection of input data. A total of 1000 samples from the photovoltaic device were collected out of which around $70 \%$ viz. 700 samples were used for network processing, while the remaining samples were used for validation and testing. These data samples are voltage and current which are used to train a neural network for solar PV model. Fig. 17 and Fig. 18 shows subsystem and detailed subsystem model of ANN based MPPT controller.

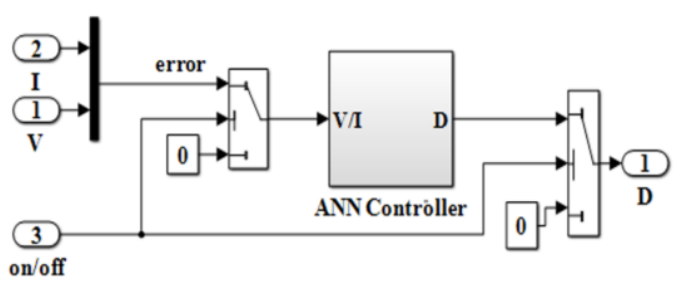

Fig. 17 Sub-System for ANN based MPPT Controller

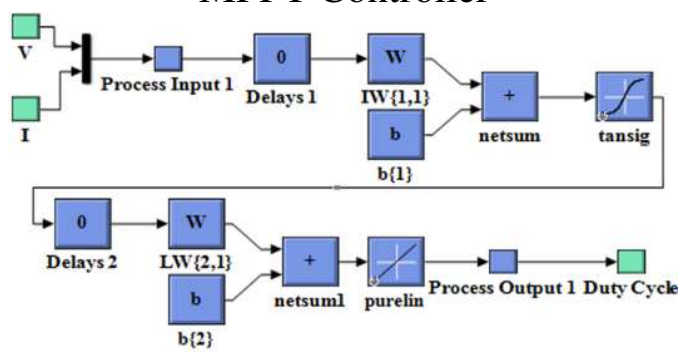

Fig. 18 Details Sub-System of ANN based MPPT Controller 


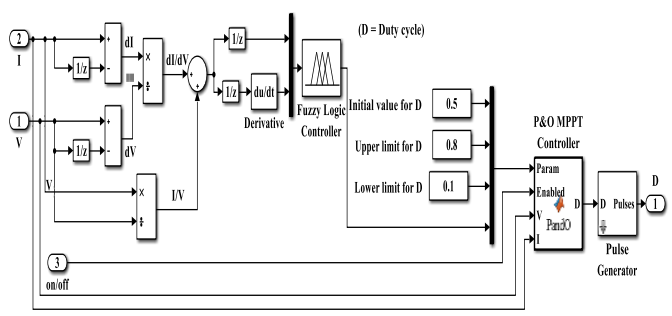

Fig. 19 Subsystem of Proposed AIAPO Controller

Similarly, Fig. 17 and Fig. 19 show the subsystems of ANN and proposed AIAPO MPPT methods. The investigator analyzed the system by including the subsystem of ANN and proposed AIAPO MPPT controllers in the block MPPT controller in the simulation model shown in Fig. 13.

\section{Results and Discussions}

Fig. 20 shows the input power, voltage and current characteristics of boost converter without MPPT Method. Fig. 21 to Fig. 24 shows the output power, voltage and current characteristics of a boost converter with PO, FL, ANN and proposed AIAPO MPPT Methods respectively. Fig. 25 to Fig. 27 show the comparative characteristics of the output power, voltage and current using PO, FL, ANN and proposed MPPT controllers.

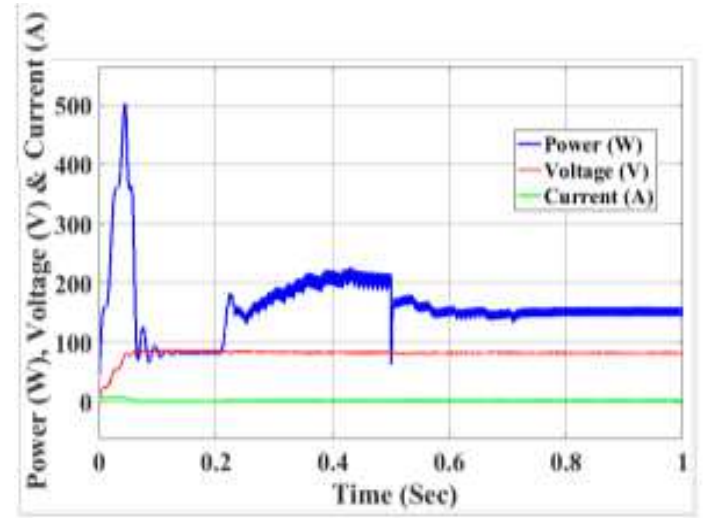

Fig. 20 Input Power, Voltage and

Current of Boost converter without MPPT Method

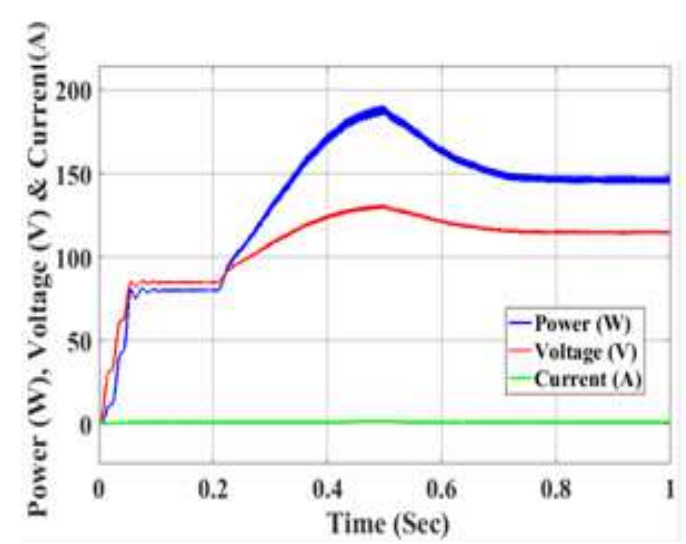

Fig. 21 Output Power, Voltage and Current of Boost Converter with PO Based MPPT Method

Simulation analysis
MATLAB $^{\mathrm{TM}} /$ SIMULINK $^{\mathrm{TM}}$ performed in order to calculate MP from the PV array. The simulation of the model has completed in one second. In Fig. 20, it is clearly observed that the input power, voltage and current values of the boost converter are $154 \mathrm{~W}, 82 \mathrm{~V}$ and $0.67 \mathrm{~A}$ respectively. Fig. 21 clearly shows that the output power, voltage and current values of the boost converter with PO MPPT method are $169.1 \mathrm{~W}, 127 \mathrm{~V}$ and $1.43 \mathrm{~A}$ respectively.

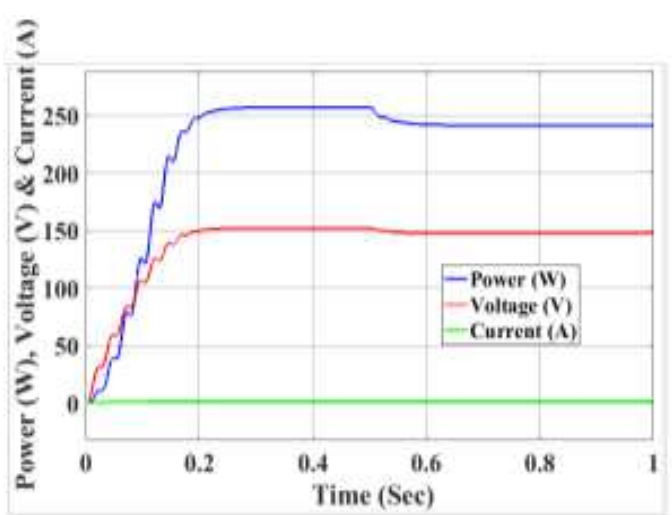

Fig. 22 Output Power, Voltage and Current of Boost Converter with FL Based MPPT Method 


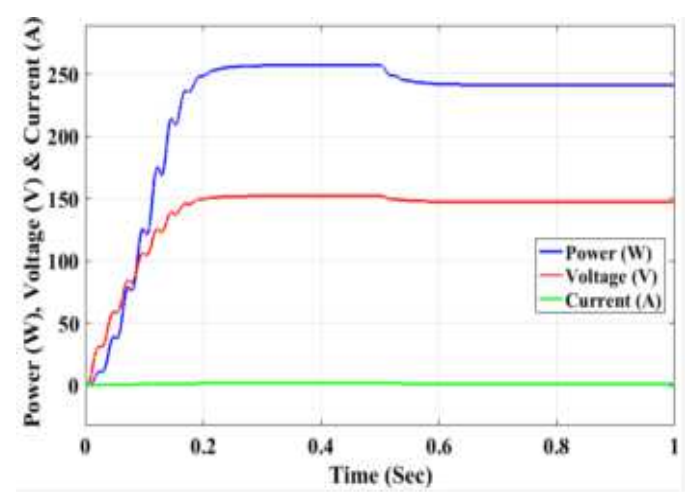

Fig. 23 Output Power, Voltage and Current of Boost Converter with ANN Based MPPT Method

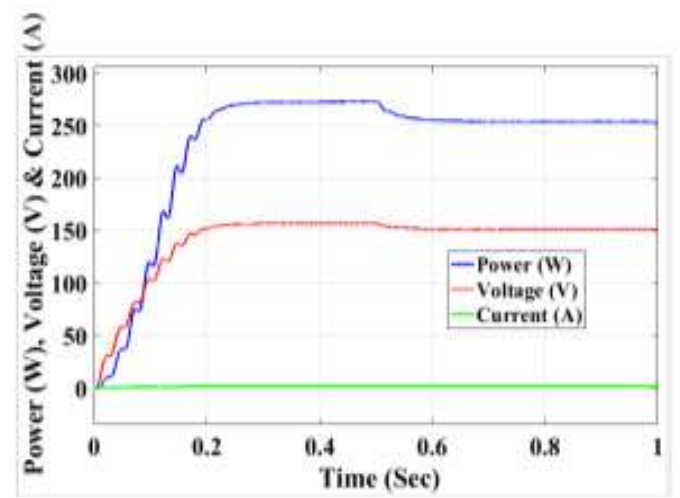

Fig. 24 Output Power, Voltage and

Current of Boost Converter with

Proposed MPPT Method

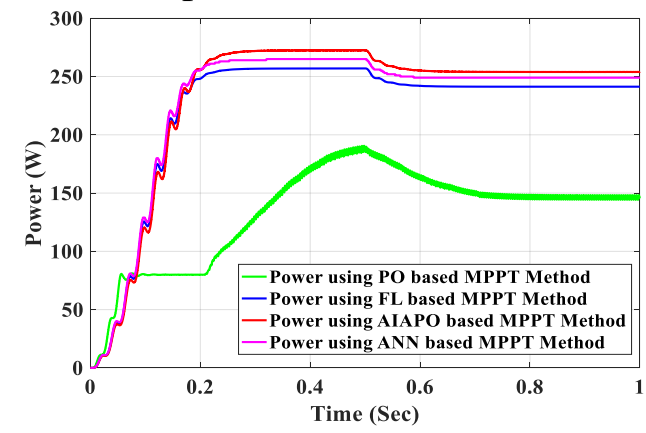

Fig. 25 Comparative Characteristics of Power using PO, FL, ANN and Proposed MPPT Method

Fig. 22 shows that the boost converter output in the form of power, voltage and current values with FL based MPPT technique are $256.9 \mathrm{~W}$, $152 \mathrm{~V}$ and 1.69A respectively, Fig. 23 shows the characteristic values of $265 \mathrm{~W}, 154 \mathrm{~V}$ and $1.71 \mathrm{~A}$ for Power, voltage and current respectively and Fig. 24 shows that the output power, voltage and current values of a boost converter with proposed MPPT technique are $272.4 \mathrm{~W}, 157 \mathrm{~V}$ and $1.74 \mathrm{~A}$ respectively.

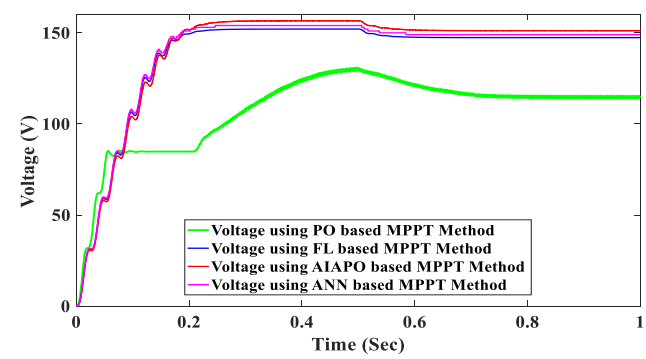

Fig. 26 Comparative Characteristics of Voltage using PO, FL, ANN and Proposed MPPT Method

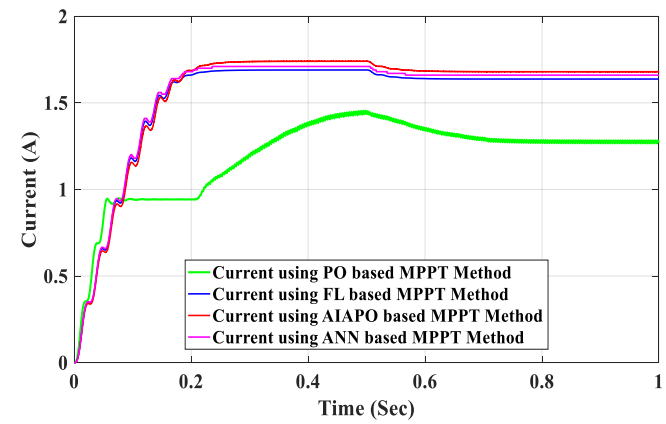

Fig. 27 Comparative Characteristics of Current using PO, FL, ANN and Proposed MPPT Method

The output of boost converter shows an increase during $0-0.5$ seconds. During the period $0.5-1$ seconds, when there is a fall in irradiation (as shown in Fig. 14), There is the case when a PO based MPPT controller is used. With FL and proposed MPPT controller, the drop in values of the output voltage and power of boost converter during $0.5-1$ second is reduced as is clearly seen in Fig. 21 to Fig. 24. Hence the output values increase to $272.4 \mathrm{~W}, 157 \mathrm{~V}$ and $1.74 \mathrm{~A}$. Using proposed AIAPO MPPT provides more accurate and stable result as compared to PO, FL and ANN based MPPT Technique. As per the experimentation performed by various MPPT techniques are carried out for PV system. Fig. 25 to Fig. 27 are clearly indicating that the comparative analysis of power, voltage and current 
performance of PV system (i.e. have been recorded $272.4 \mathrm{~W}, 157 \mathrm{~V}$ and 1.74A) using proposed MPPT method which is better than the PO based MPPT (i.e. 169.1W, 127V, 1.43A), FL based MPPT technique (i.e. $256.9 \mathrm{~W}$, $152 \mathrm{~V}, 1.69 \mathrm{~A})$ and ANN based MPPT technique (i.e. $265 \mathrm{~W}, 154 \mathrm{~V}, 1.71 \mathrm{~A}$ ) correspondingly.

In order to show the feasibility and performance of the proposed AIAPO MPPT controller, a simulation study has been carried out using the PV system. Combined results with different MPPT systems for power, voltage and current waveforms are as shown in Fig. 25 to Fig. 27 respectively. Proposed MPPT technique based system is always found to be a better option for obtaining maximum values of power, voltage and current correspondingly.

\section{Comparative Analysis of Different MPPT Controllers in Solar-PV System}

The simulation results for different MPPT techniques for the photo-voltaic system are described in this research article. The comparative analysis of the performance parameters such as power, voltage and current are shown in Fig. 25 to Fig. 27. Table 3 and Fig. 28 show the summarized simulation results.

Table 3: Comparison of Performance Parameters in PV System with different MPPT Method

\begin{tabular}{|c|c|c|c|c|}
\hline $\begin{array}{l}\text { Sr. } \\
\text { No }\end{array}$ & Method & $\begin{array}{c}\text { Power } \\
\text { (W) }\end{array}$ & $\begin{array}{l}\text { Voltag } \\
\text { e (V) }\end{array}$ & $\begin{array}{l}\text { Curren } \\
\mathrm{t}(\mathrm{A})\end{array}$ \\
\hline 1 & $\begin{array}{l}\text { Without } \\
\text { MPPT }\end{array}$ & $154 \mathrm{~W}$ & $82 \mathrm{~V}$ & $0.67 \mathrm{~A}$ \\
\hline 2 & $\begin{array}{l}\text { PO } \\
\text { based } \\
\text { MPPT }\end{array}$ & $\begin{array}{l}169.1 \\
W\end{array}$ & $127 \mathrm{~V}$ & $1.43 \mathrm{~A}$ \\
\hline 3 & $\begin{array}{l}\text { FL } \\
\text { based } \\
\text { MPPT }\end{array}$ & $\begin{array}{l}256.9 \\
\text { W }\end{array}$ & $152 \mathrm{~V}$ & $1.69 \mathrm{~A}$ \\
\hline 4 & $\begin{array}{l}\text { ANN } \\
\text { based } \\
\text { MPPT }\end{array}$ & $265 \mathrm{~W}$ & $154 \mathrm{~V}$ & $1.71 \mathrm{~A}$ \\
\hline 5 & Propose & 272.4 & $157 \mathrm{~V}$ & $1.74 \mathrm{~A}$ \\
\hline
\end{tabular}

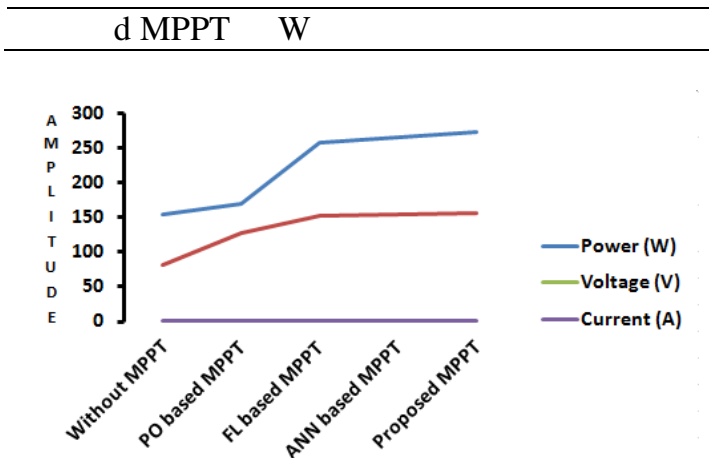

Fig. 28 Comparative Characteristics of Different MPPT techniques in PV System

It is found that the power generation from proposed MPPT technique is more as compared to PO, FL and ANN based MPPT technique. Therefore integration of two MPPT techniques is very important for power production in the photo-voltaic system. The proposed hybrid MPPT method is found to be more efficient in producing power in PV system i.e. $272.4 \mathrm{~W}$ as compared to other MPPT techniques.

It is clearly seen that the proposed hybrid technique gives the better performance as compared to conventional MPPT technique.

\section{Conclusion}

In this study, the different MPPT methods of the PV system such as PO, FL, ANN and proposed hybrid method is used to find a most feasible method for the PV system. The aim of this paper is to track MPP from the solar PV array by the proposed hybrid controller for irradiation changes and comparing results with PO, FL and ANN based MPPT controllers. Different MPPT techniques have been used to compute MPP and improved efficiency of the PV panel. In this paper, AIAPO, ANN, FL and PO MPPT methods have been chosen to obtain this objective. Simulation results showing that the system in which proposed control method has been used gives better 
performance and reduce fluctuations of the MPP as compared to PO, FL and ANN based MPPT technique at rapid changes of irradiation.

It is also evident that the maximum power produced by the proposed hybrid technique is considerably high. The investigator would like to assert that hybrid technique of RE source like PV system for power generation is a better option for rural areas where conventional power supply from the grid is rarely available.

This research is utilized for the stand-alone system as well as a grid. Further research in MPPT based system assistances to pick particular MPPT control method for a precise application, and correspondingly in the area of MPPT techniques and hybrid MPPT techniques. Use of this technique may enhance the output of the proposed system.

\section{Declaration}

Ethics approval and consent to participate

Not Applicable

\section{Consent for publication}

Author has given their consent for this article to be considered for publication.

\section{Availability of supporting data}

Data and additional materials are available on request.

\section{Competing interests}

The author declare that author has no competing interests.

\section{Funding}

The author received no funding for this study.

\section{Authors' contributions}

All sections of the article including idiea, concepts, writing, and proofreading was done by the author. The author reads and approved the final manuscript.

\section{Acknowledgements}

The author is grateful to the Department of Electrical and Electronics, Mewat Engineering College, Nuh, Haryana. Again, the reviewers have demonstrated excellent knowledge in the subject area, with constructive and well-presented criticisms and opinions. I say a million thanks to the reviewers, chief editor, and the editorial office. This journal is highly recommended for professionalism and excellent delivery of service.

\section{References}

Ahmed, A. S., Abdullah, B. A., \& Abdelaal, W. G. A. (2016). MPPT algorithms: Performance and evaluation. Proc. in IEEE on 
Computer Engineering \& Systems (ICCES), pp. 461-467.

Algazar, M. M., Al-Monier, H., ElHalim, H. A, \& Salem, M. E. E. (2012). Maximum Power Point Tracking Using Fuzzy Logic Control. Elsevier Journal on Electrical Power and Energy System, 39(1), 21-28.

Balasubramanian, G., \& Singaravelu, S. (2012). Fuzzy logic controller for the maximum power point tracking in photovoltaic system. International Journal of Computer Applications, 41(12), 22-28.

Basoglu, M. E. (2018). An enhanced scanning-based MPPT approach for DMPPT systems. International Journal of Electronics, 105(12), 2066-2081. doi: $10.1080 / 00207217.2018 .1494332$

Bounechba, H., Bouzid, H., Nabti, K., \& Benalla, H. (2014). Comparison of Perturb \& Observe and Fuzzy Logic in Maximum Power Point Tracker for PV Systems. Energy Procedia, 50, 677-684.

Chu, C. C, \& Chen, C. L. (2009). Robust maximum power point tracking method for photovoltaic cells: A sliding mode control approach. Solar Energy, 83(8), 13701378.

Dimitrijevic, M., Stosovic, M. A., \& Litovski, V. B. (2020). An MPPT controller model for a standalone PV system. International Journal of Electronics, 1-19. doi: 10.1080/00207217.2020.1726492

El-Helw, H. M., Magdy, A. \& Marei, M. I. (2017). A Hybrid Maximum Power Point Tracking Technique for Partially Shaded Photovoltaic Arrays. IEEE Access, 5, 1190011908.

Femia, N., Petrone, G., Spagnuolo, G., \& Vitelli, M. (2009). A technique for improving $\mathrm{P} \& \mathrm{O} \quad \mathrm{MPPT}$ performances of double-stage grid- connected photovoltaic systems. IEEE transactions on industrial electronics, 56(11), 4473-4482.

Hohm, D. P., \& Ropp, M. E. (2000). Comparative Study of Maximum Power Point Tracking Algorithms Using an Experimental, Programmable, Maximum Power Point Tracking Test Bed. Proc. In IEEE of photovoltaic specialists conference, pp. 1699-1702.

Khan M. J., \& Mathew, L. (2016a). Different Kinds of Maximum Power Point Tracking control method for Photovoltaic Systems: A Review. Springer, Achieves of Computational Method, 24(4), 855-867.

Khan, M. J. \& Mathew L. (2019b). Comparative study of maximum power point tracking techniques for hybrid renewable energy system. International Journal of Electronics, 106(8), 1216-1228.

Khan, M. J., \& Mathew, L. (2019c). Fuzzy Logic Controller-based MPPT for Hybrid Photo-Voltaic/Wind/Fuel Cell Power System. Neural Computing and Applications, 31(10), 6331-6344.

Letting L. K, Munda, J. L., \& Hamam, Y. (2014). Optimisation and rule firing analysis in fuzzy logic based maximum power point tracking. Journal of Intelligent \& Fuzzy Systems, 27(3), 1267-76.

Letting, L. K., Munda, J. L., \& Hamam, Y. (2014). Optimisation and rule firing analysis in fuzzy logic based maximum power point tracking. Journal of Intelligent \& Fuzzy Systems, 27(3), 1267-1276.

Liu, P., Yang, W. T., Yang, C. E., \& Hsu, C. L. (2015). Sensorless wind energy conversion system maximum power point tracking using TakagiSugeno fuzzy cerebellar model articulation control. Applied Soft Computing, 29, 450-60. 
Lorenzo, E. (1994). Solar Electricity: Engineering of Photovoltaic Systems. Progensa, 78-80. ISBN 8486505-55-0

Mahalakshmi, D., Archana, V. S., \& Komathi, J. (2016). Reactive power control in microgrid by using Photovoltaic Generators. Proc. in IEEE on Computation of Power, Energy Information and Commuincation (ICCPEIC), pp. $762-767$.

Mahamudul, H., Saad, M., \& Ibrahim Henk, M. (2013). Photovoltaic system modeling with fuzzy logic based maximum power point tracking algorithm. International Journal of Photo energy, 2013, 1-10. doi: 10.1155/2013/762946

Nabizadeh, H., Alizadeh, M. R., Afifi, A., \& Soltani, I. (2013). Identification of Optimal Operating Point of PV Modules Using Fuzzy Logic Control. International Journal of Electronics Communication and Computer Engineering, 4(6), 16071611.

Ravindran, V., \& Sutaria, J. (2016). Implementation in arm microcontroller to maximize the power output of solar panel using Hill Climbing Algorithm. Proc. in IEEE on Electrical, Electronics, and Optimization Techniques (ICEEOT), pp. 1234-1240.

Robles Algarin, C., Taborda Giraldo, J., \& Rodriguez Álvarez, O. (2017). Fuzzy logic based MPPT controller for a PV system. Energies, 10(12), 118.

Sawant, F. T., Bhattar, P. L., \& Bhattar, C. L. (2017). Review on maximization of solar system under uniform and non uniform conditions. Proc. in IEEE on Circuit, Power and Computing Technologies (ICCPCT), pp. 1-7.

Sawant, P. T., Lbhattar, P. C., \& Bhattar, C. L. (2016). Enhancement of PV system based on artificial bee colony algorithm under dynamic conditions. Proc. in IEEE on Recent Trends in Electronics, Information \& Communication Technology (RTEICT), pp. 1251-1255.

Selami Balci, A. K. \& Berat, Y. (2020) ANN-based estimation of the voltage ripple according to the load variation of battery chargers, International Journal of Electronics, 107(1), 17-

27. doi: 10.1080/00207217.2019.159 1530

Shahana, P. S., \& Linus, R. M. (2016). Modified maximum power point tracking for PV system using single switch DC/DC converter. Proc. in IEEE on Electrical, Electronics, and Optimization Techniques (ICEEOT), 3156-3160.

Spagnuolo, G., Petrone, G., Araujo, S. V., \& Cecati, C. (2010). Renewable energy operation and conversion schemes: A summary of discussions during the seminar on renewable energy systems. IEEE Industrial Electronics Magazine, 4(1), 38-51.

Ulapane, N. N., Abeyratne, S. G. (2014). Gaussian process for learning solar panel maximum power point characteristics as functions of environmental conditions. Proc. in IEEE on Industrial Electronics and Applications (ICIEA), pp. 1756-1761. Vivek, P., Ayshwarya, R., Amali, S. J., \& Sree, A. N. (2016). A novel approach on MPPT algorithm for solar panel using buck boost converter. Proc. in IEEE on Energy Efficient Technologies for Sustainability (ICEETS), pp. 396399. 
Figures

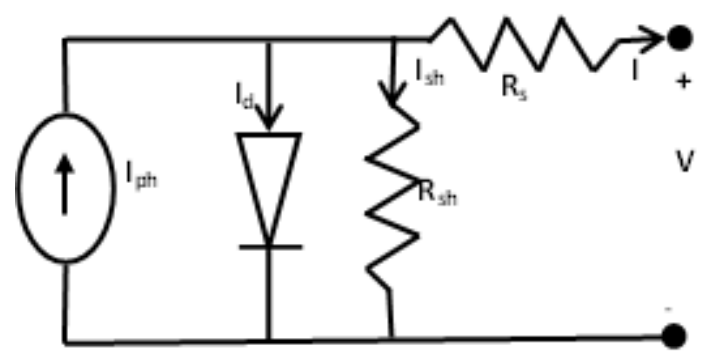

Figure 1

Solar Cell Equivalent Circuit

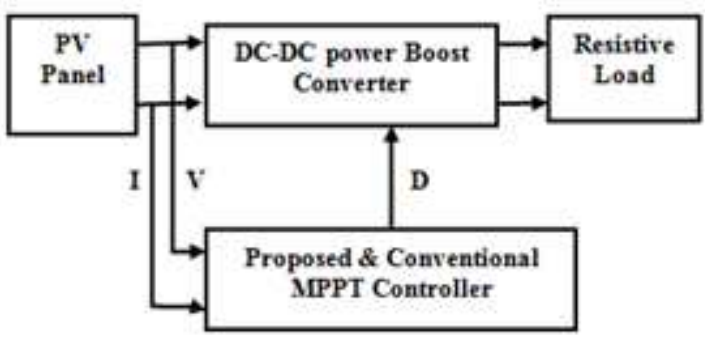

Figure 2

Block Diagram of Proposed PV Renewable Energy System 


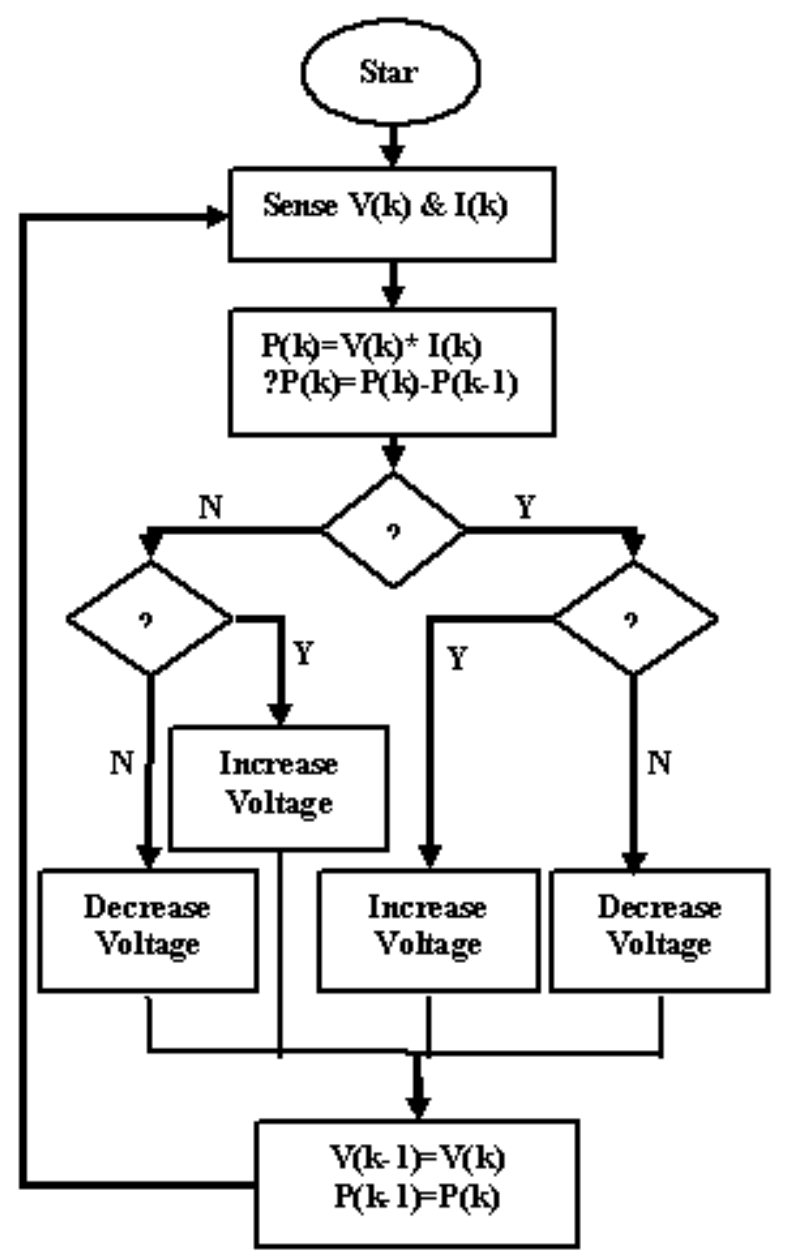

Figure 3

Flow Chart of PO Control Method

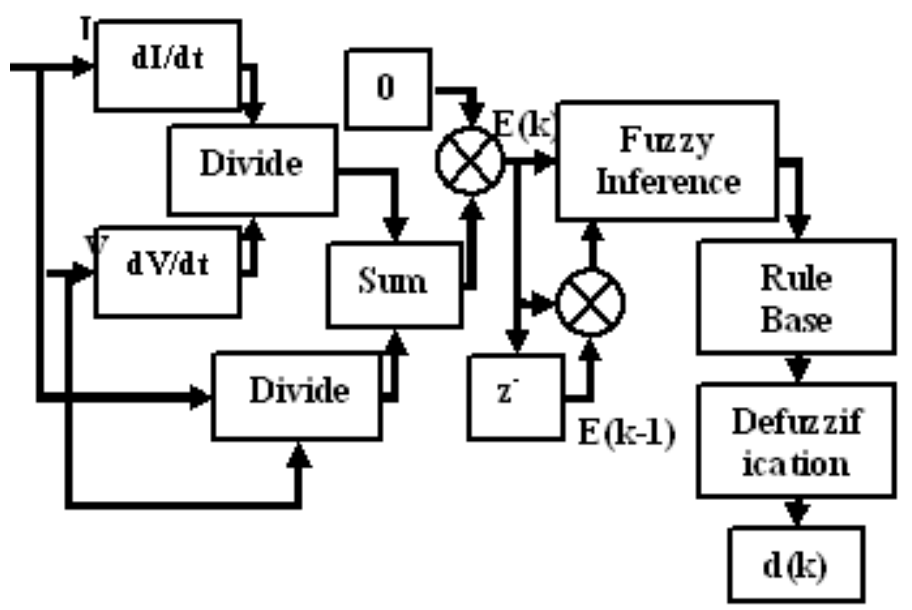

Figure 4 


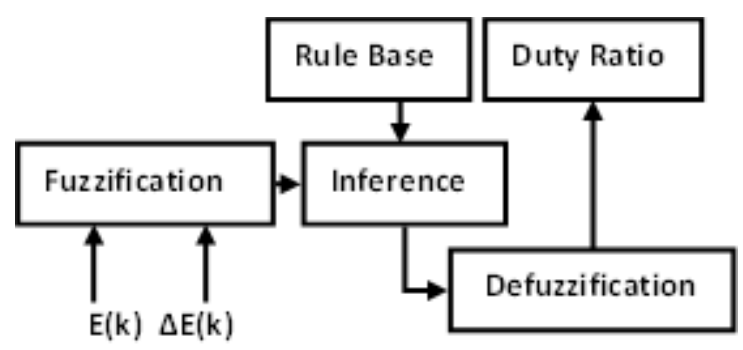

Figure 5

Block Diagram of FL Approach

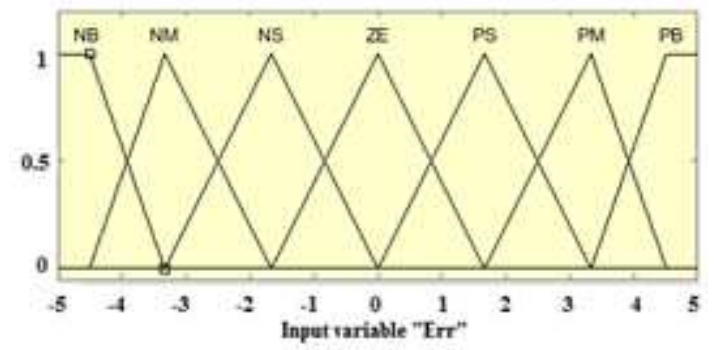

Figure 6

Membership Function (MF) of Input (Err)

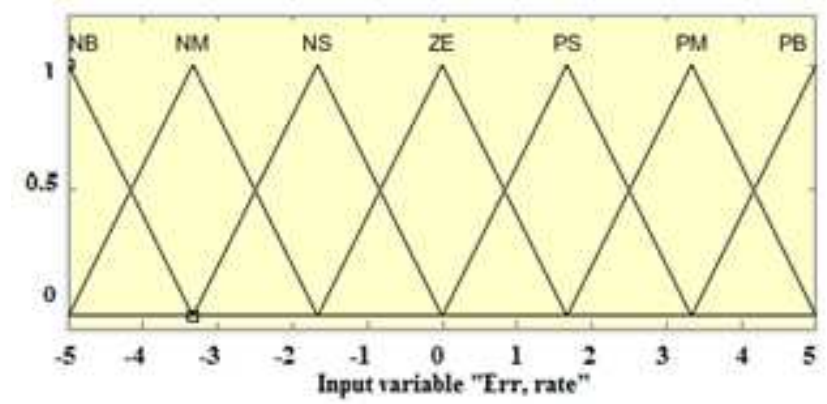

Figure 7

Membership Function (MF) of Input (Err,ate)

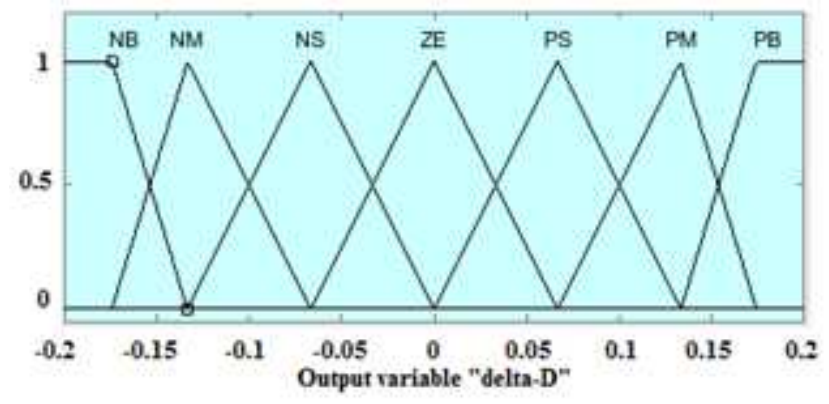

Figure 8

Membership Function (MF) of Output (delta-D) 


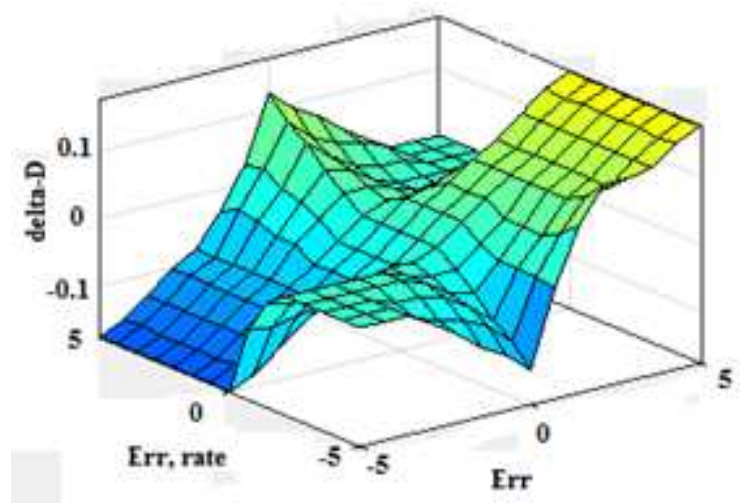

Figure 9

Surface Viewer of FL Controller

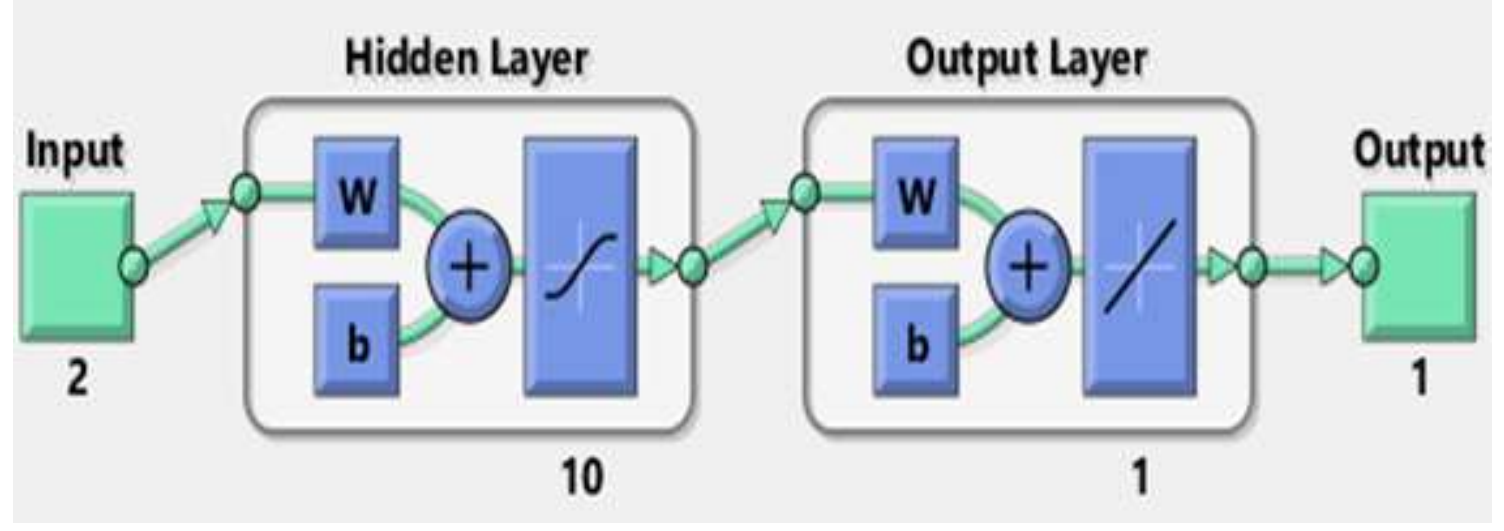

Figure 10

ANN Model

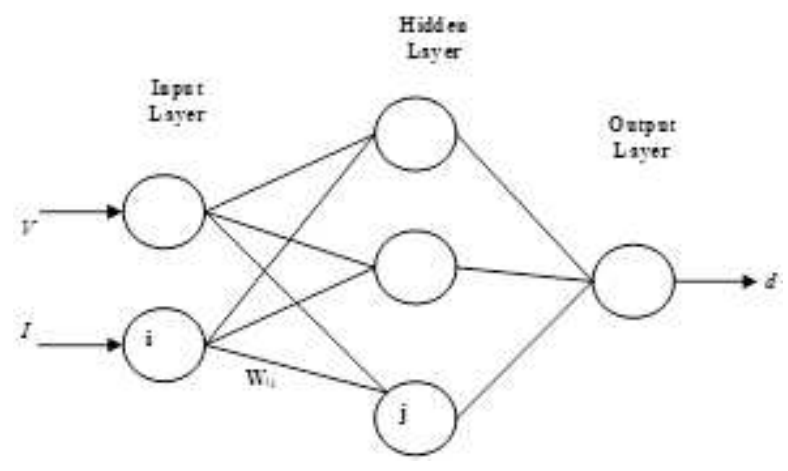

Figure 11

ANN based MPPT Technique 


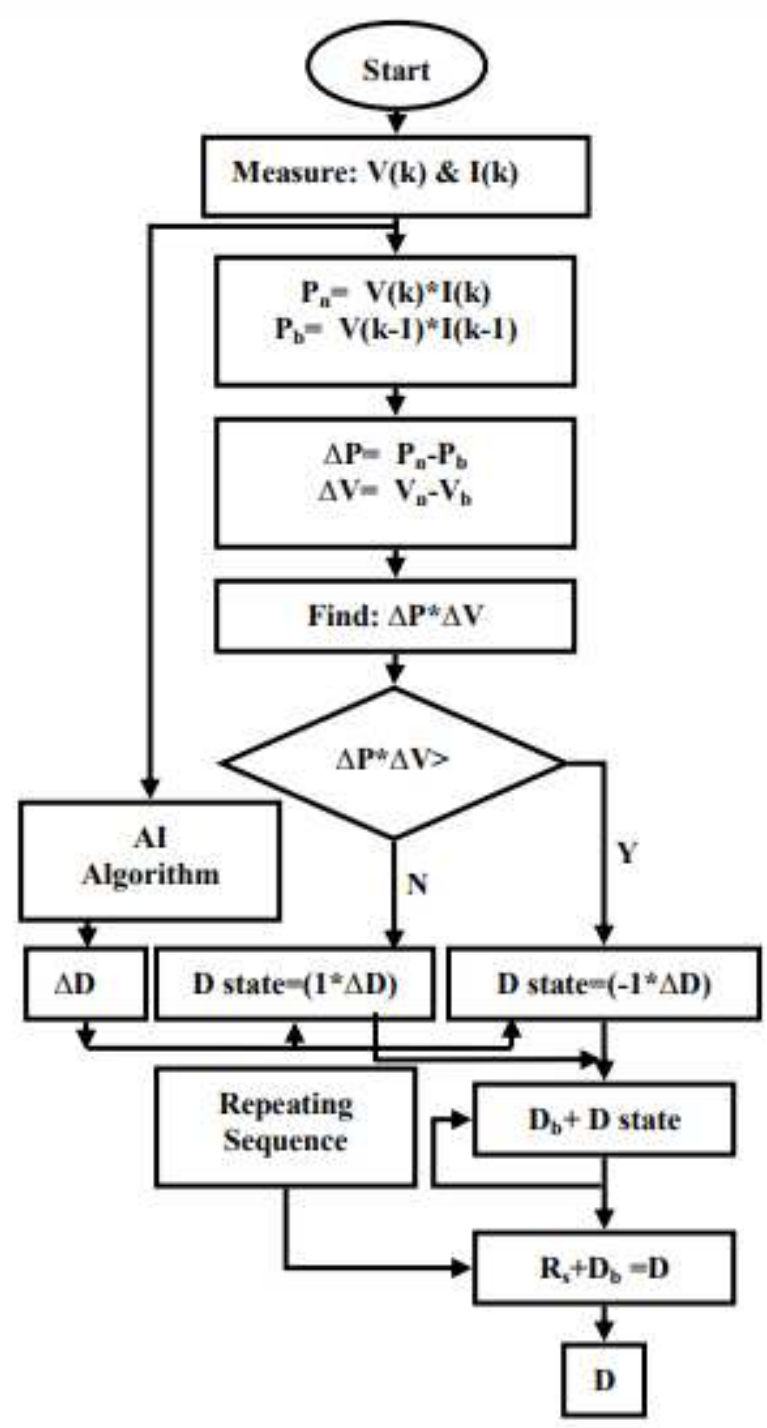

Figure 12

Flowchart of AIAPO MPPT Controller

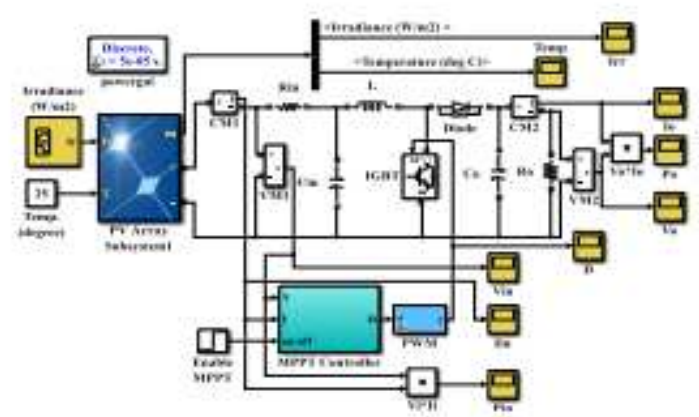

Figure 13

Simulation Model of Solar-PV System using MPPT Controller 


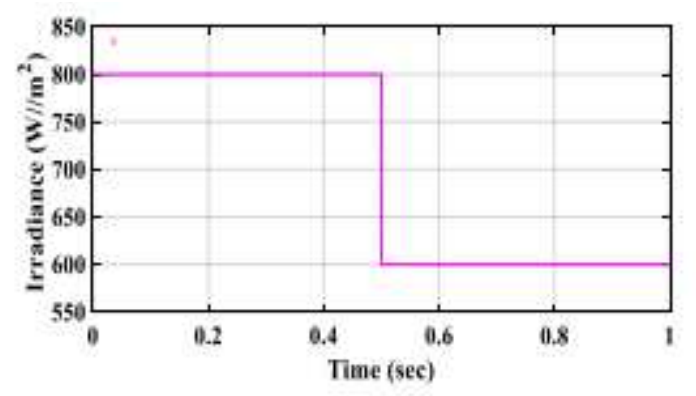

Figure 14

Irradiation Pattern of Input for PV Panel

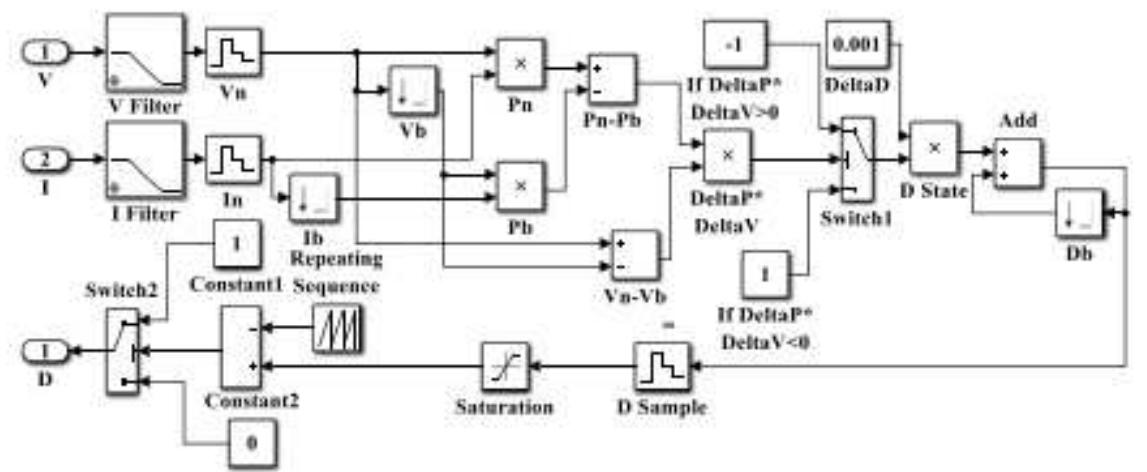

Figure 15

Subsystem of PO Controller

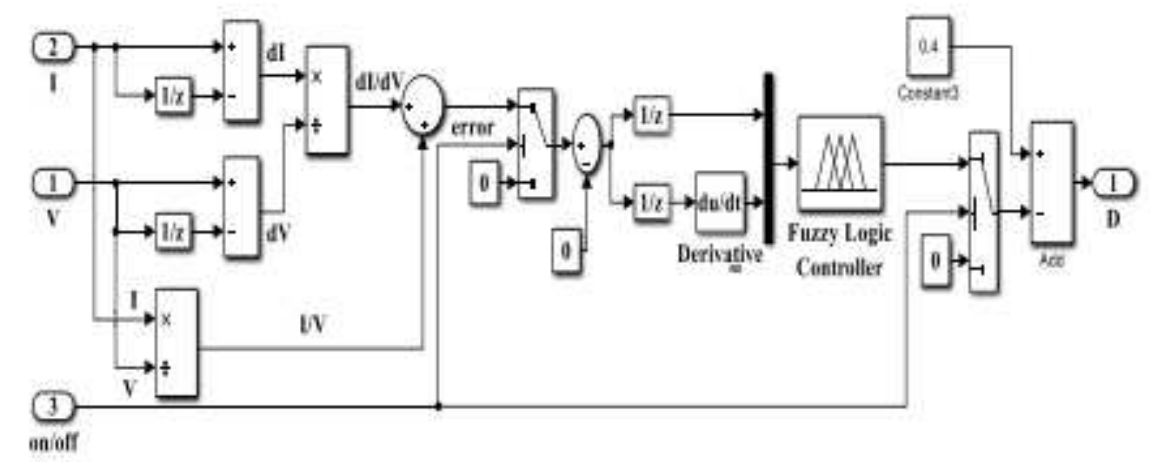

Figure 16

Subsystem of Fuzzy Logic Controlle 


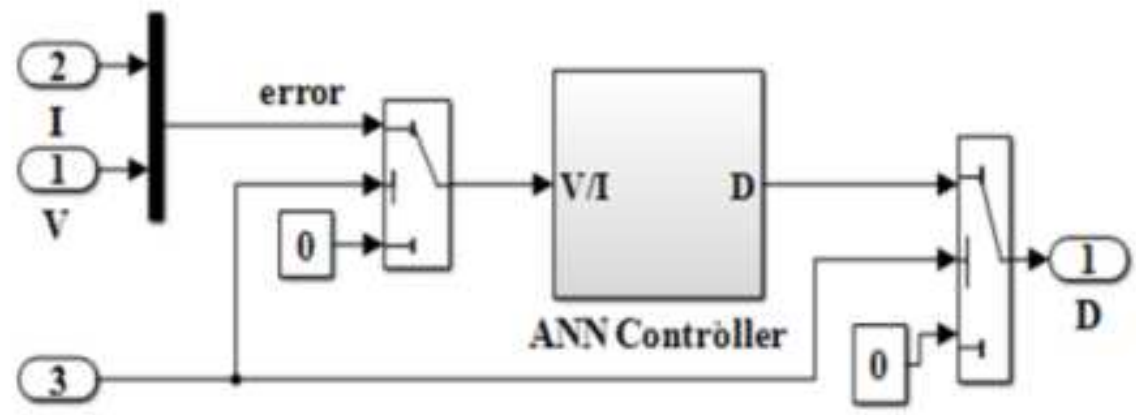

on/off

Figure 17

Sub-System for ANN based MPPT Controller
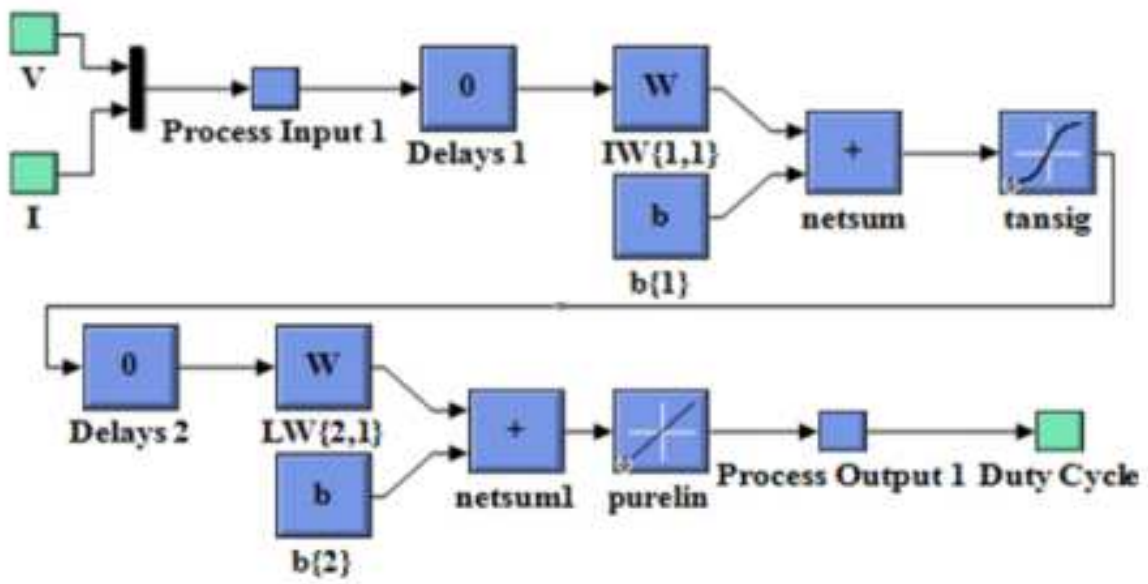

Figure 18

Details Sub-System of ANN based MPPT Controller

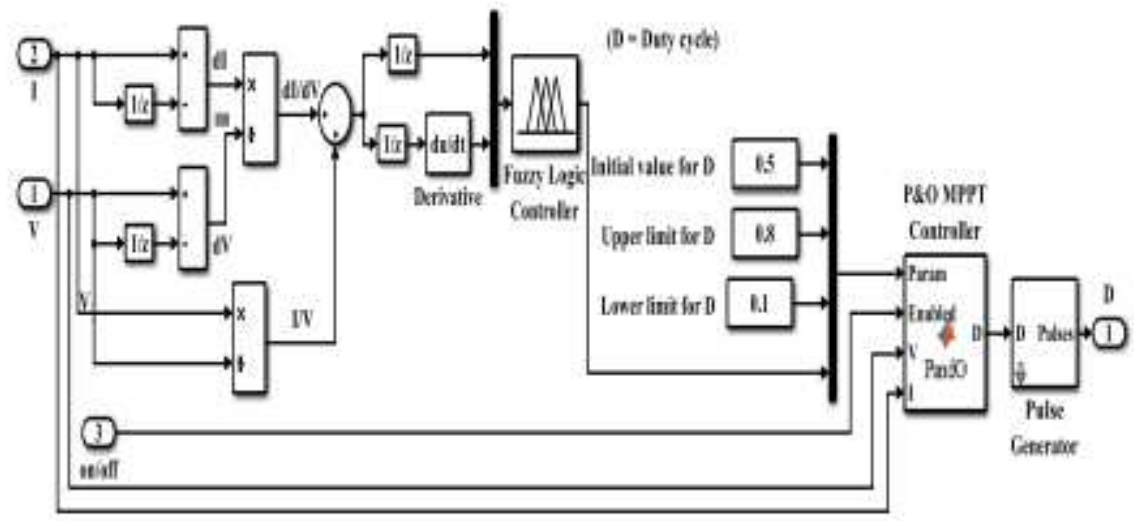

Figure 19

Subsystem of Proposed AIAPO Controller 


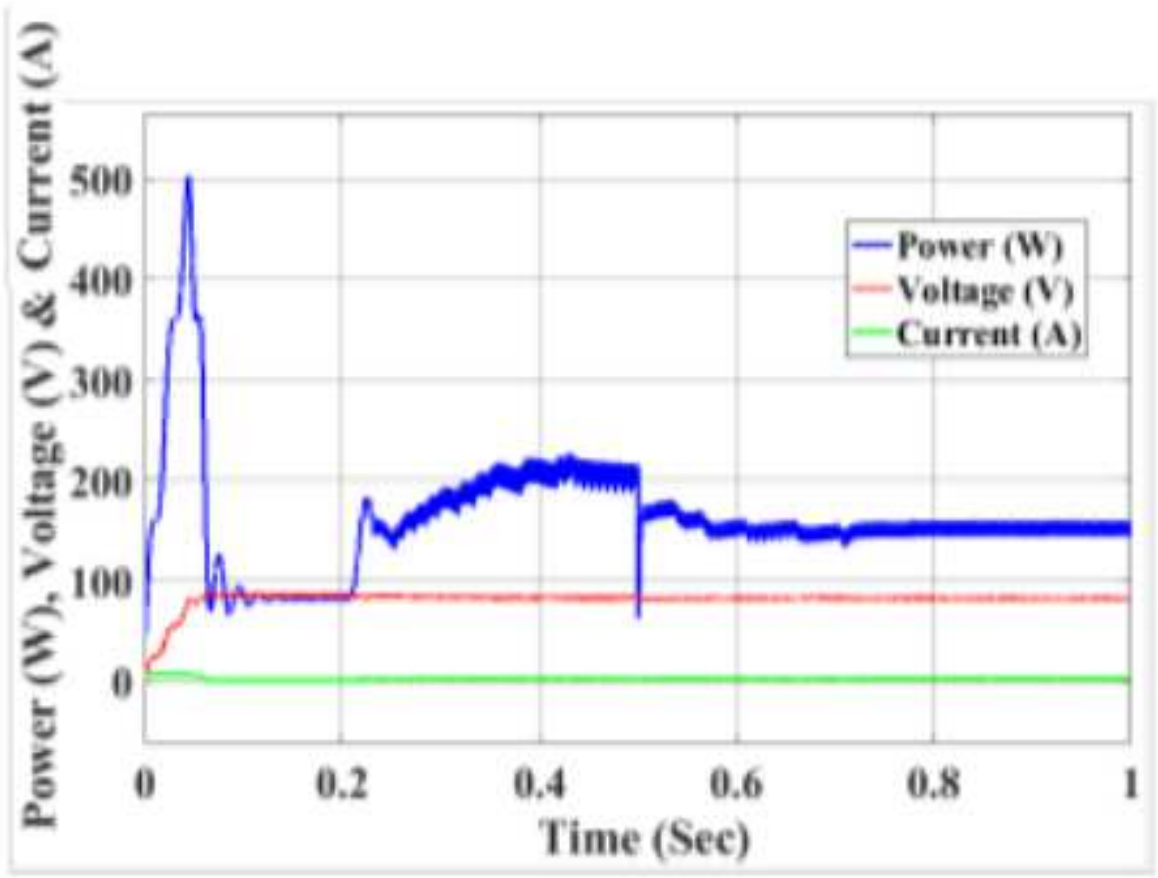

Figure 20

Input Power, Voltage and Current of Boost converter without MPPT Method

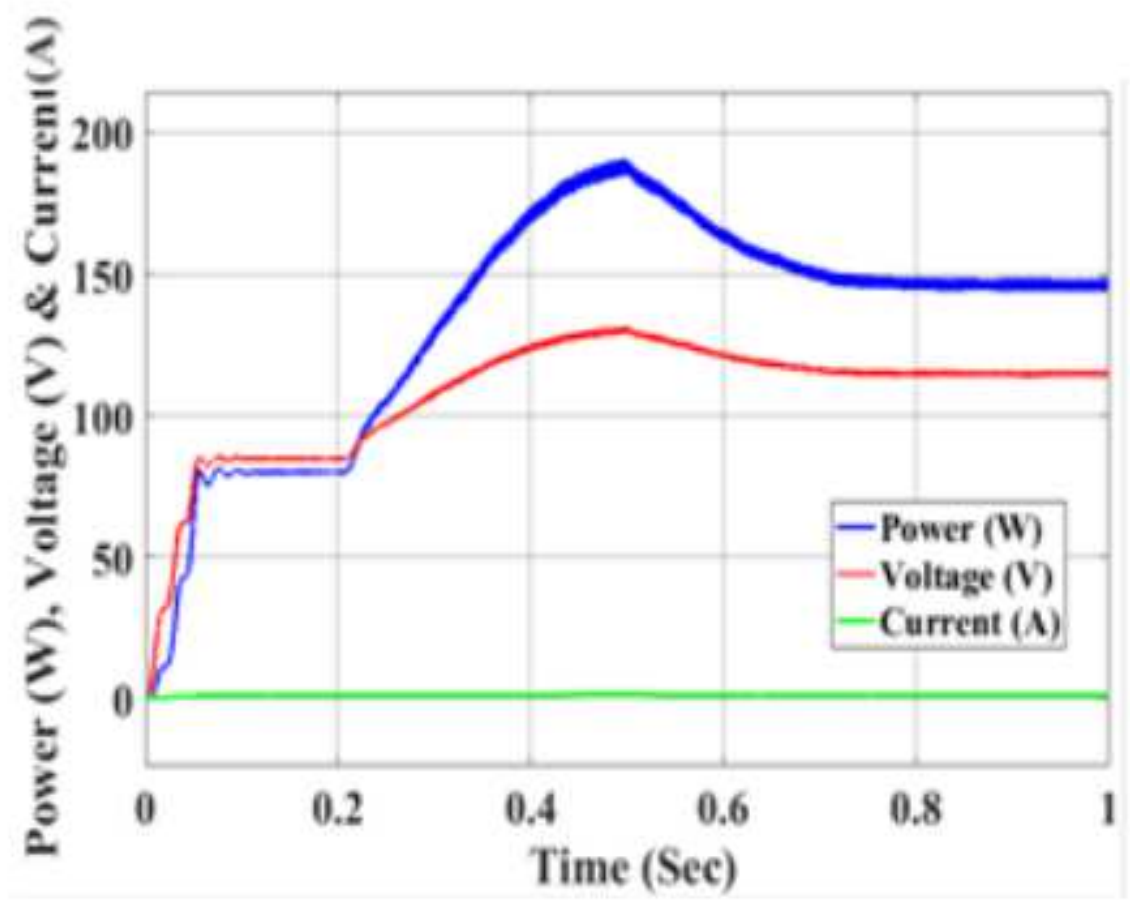

Figure 21

Output Power, Voltage and Current of Boost Converter with PO Based MPPT Method 


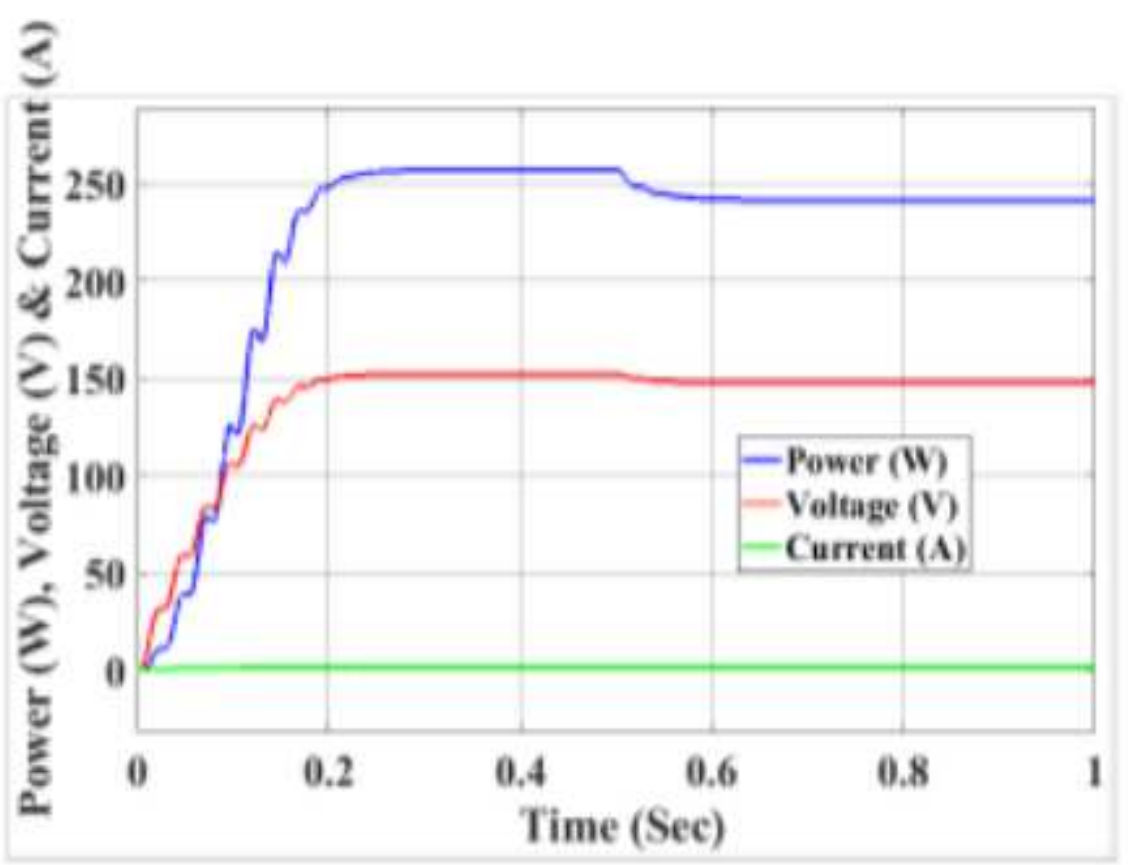

Figure 22

Output Power, Voltage and Current of Boost Converter with FL Based MPPT Method

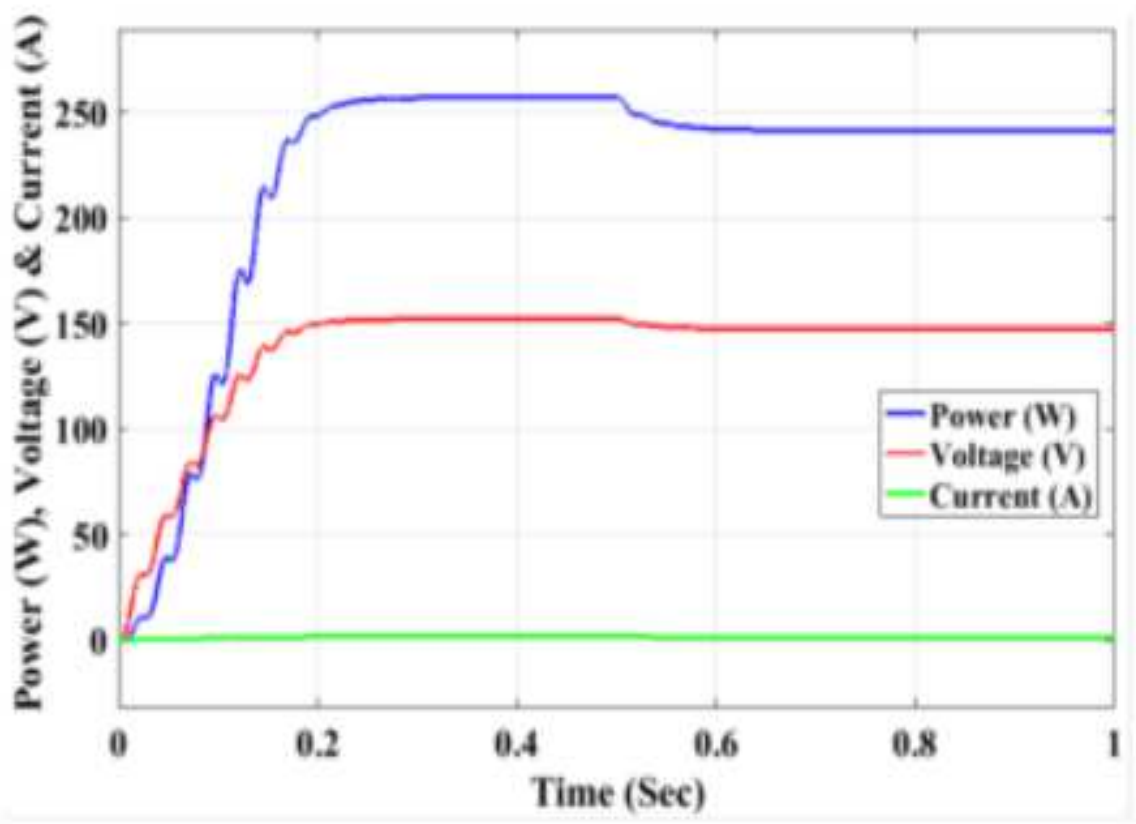

Figure 23

Output Power, Voltage and Current of Boost Converter with ANN Based MPPT Method 


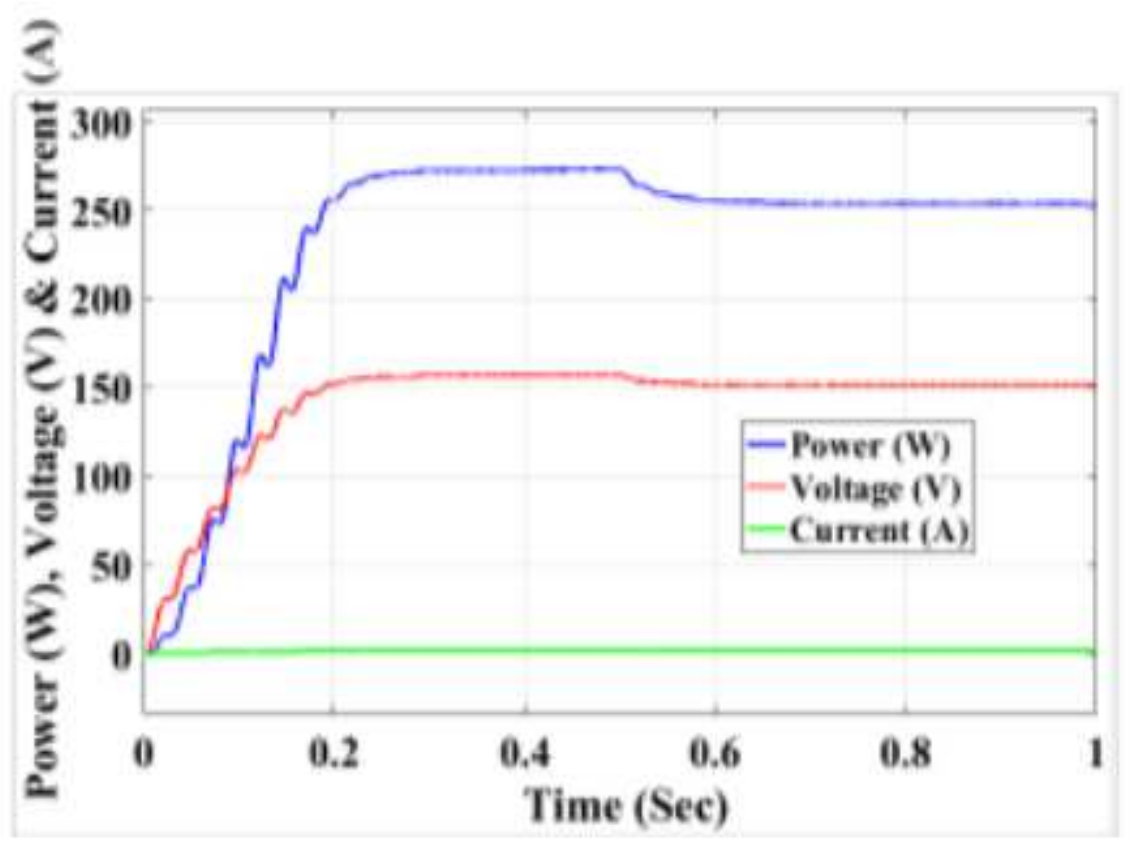

Figure 24

Output Power, Voltage and Current of Boost Converter with Proposed MPPT Method

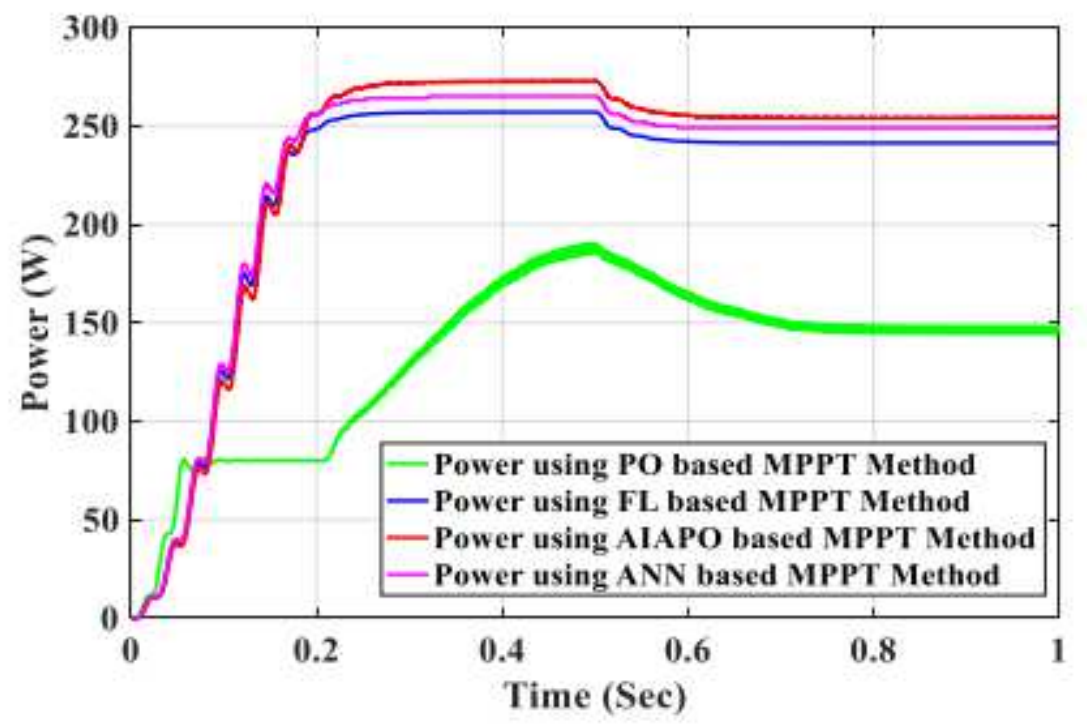

Figure 25

Comparative Characteristics of Power using PO, FL, ANN and Proposed MPPT Method 


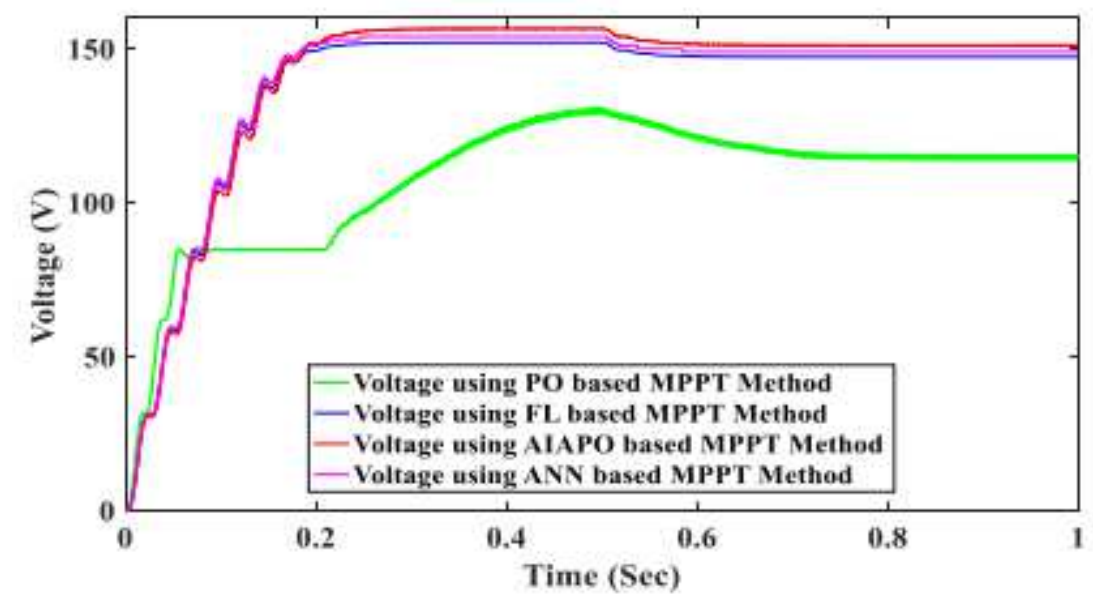

Figure 26

Comparative Characteristics of Voltage using PO, FL, ANN and Proposed MPPT Method

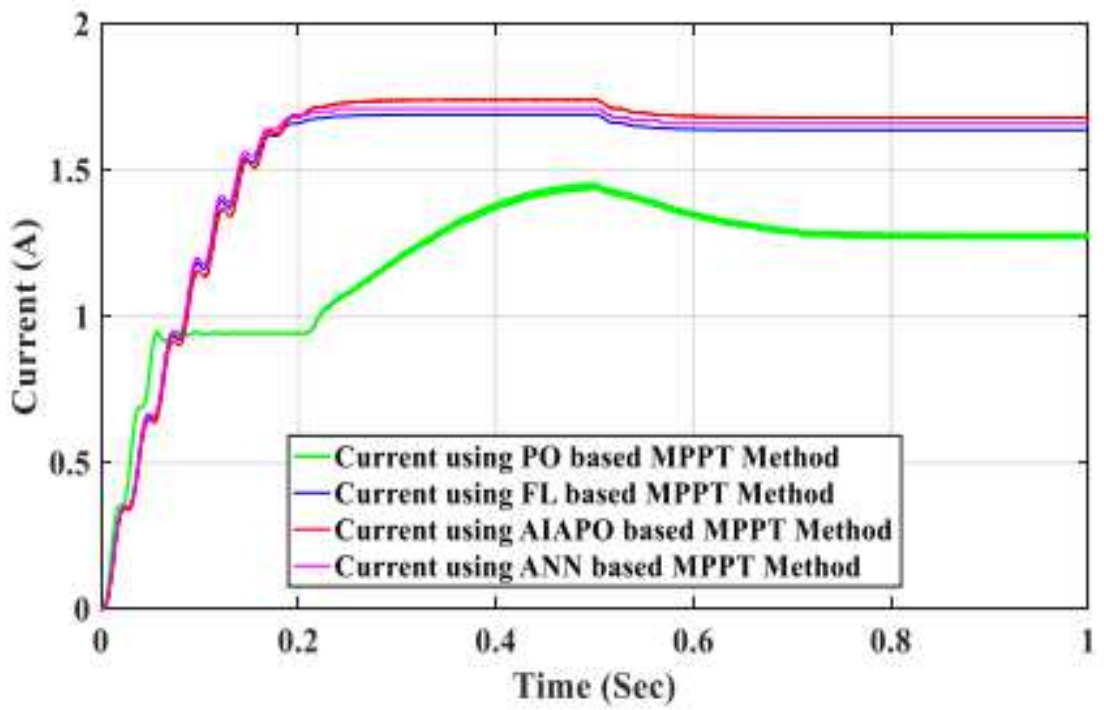

Figure 27

Comparative Characteristics of Current using PO, FL, ANN and Proposed MPPT Method 

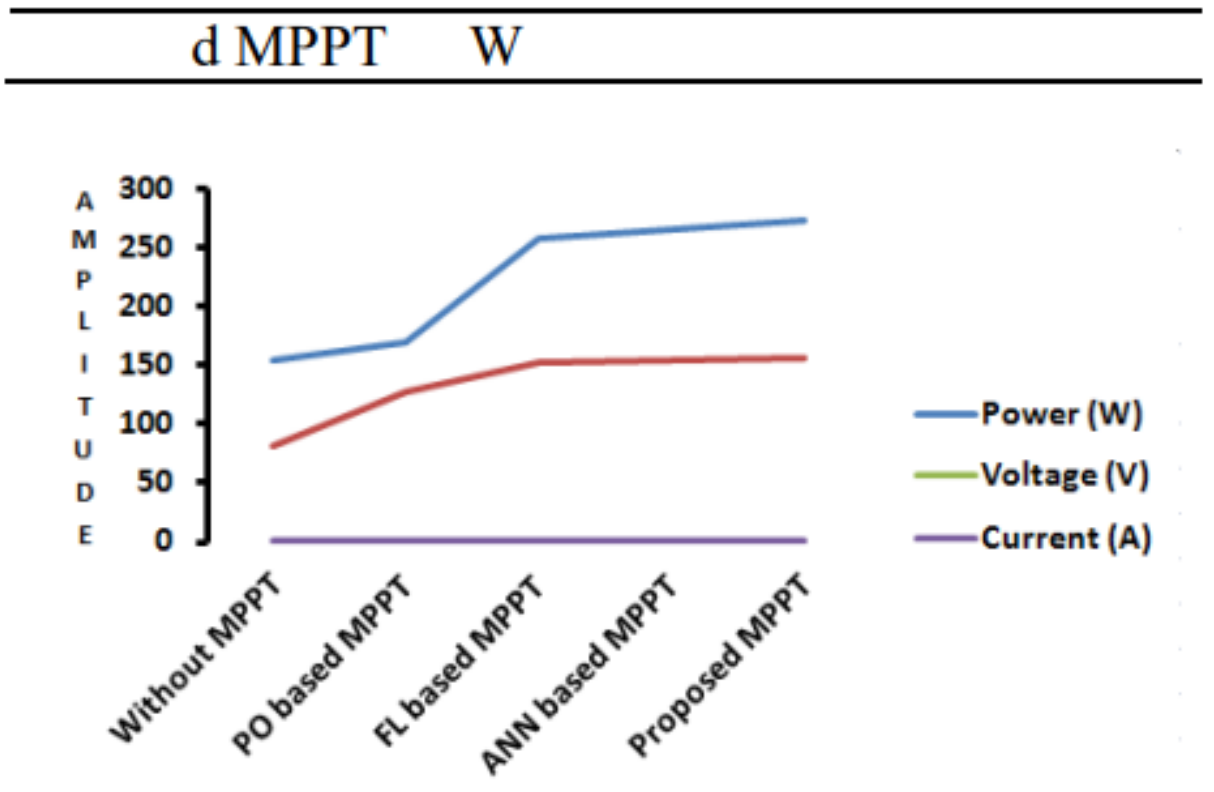

Figure 28

Comparative Characteristics of Different MPPT techniques in PV System 